\title{
Gray Matter alterations in MS and CIS: a Coordinate based Meta-analysis and
}

\section{regression}

Sonika Singh, Christopher Tench, Radu Tanasescu, Cris Constantinescu, Division of Clinical

Neuroscience, University of Nottingham

\section{Abstract}

The purpose of this coordinate based meta-analysis (CBMA) was to summarise the available evidence related to regional grey matter (GM) changes in patients with multiple sclerosis (MS) and clinically isolated syndrome (CIS). CBMA is a way to find the consistent results across multiple independent studies that are otherwise not easily comparable due to methodological differences. The coordinate based random effect size (CBRES) meta-analysis method utilizes the reported coordinates (foci of the clusters of GM loss) and Z score standardised by number of subjects, controlling type I error rate by false cluster discovery rate (FCDR). Thirty-four published articles reporting forty-five independent studies using voxel-based morphometry (VBM) for the assessment of GM atrophy between MS or CIS patients and healthy controls were identified from electronic databases. The primary meta-analysis identified clusters of spatially consistent crossstudy reporting of GM atrophy; subgroup analyses and meta-regression were also performed. This meta-analysis demonstrates consistent areas of GM loss in MS or CIS, in the form of significant clusters. Some clusters also demonstrate correlation with disease duration.

Coordinate based meta-analysis, voxel-based morphometry, grey matter atrophy, MS, CIS 
Introduction:

Areas of inflammation, axonal loss, demyelination and gliosis, occurring throughout the brain and spinal cord, are the distinctive features of Multiple Sclerosis (MS).(Confavreux, Vukusic et al. 2000) Although MS has, in the past, been considered to be a condition affecting the white matter (WM) and the hyperintense lesions on T2 weighted images are the most important MRI characteristic for MS diagnostics, there is a limited association between lesion accrual and disability, reflecting pathological heterogeneity and consequent varied impact on clinical function and nerve conduction. Atrophy measures appear to be a more specific marker of MS pathology than lesion volumes(Miller, Barkhof et al. 2002), as demonstrated by the association of atrophy in the brain and spinal cord with increasing disability.(Losseff, Wang et al. 1996) In addition, progressive ventricular enlargement, another indicator of atrophy, has been shown to predate clinically definite MS in patients with clinically isolated syndrome (CIS) over a period of 1 year.(Dalton, Chard et al. 2004)

Atrophy of GM is already observed in the initial disease stages(Calabrese, Atzori et al. 2007) and an association has been observed with cognitive decline and physical disability(Messina and Patti 2014). The underlying mechanism for GM atrophy is still unknown. Several hypotheses have been postulated including primary GM damage involving neuronal loss, demyelination, reduced synapses, decreased oligodendrocytes as well as secondary damage involving axonal transection due to lesions. (Geurts and Barkhof 2008) An association has been demonstrated between GM loss and lesion load even in patients with short disease duration.(De Stefano, Matthews et al. 2003, Sailer, Fischl et al. 2003, Tedeschi, Lavorgna et al. 2005, Fisniku, Chard et al. 2008)

VBM can be used for the identification of localised regions of GM difference relative to a control group. Multiple VBM analyses of MS or CIS patients compared to healthy control groups have been published and significant changes interpreted as atrophy. When appropriately conducted, VBM has been shown to be robust against various processing steps with false positives randomly distributed about the brain.(Scarpazza, Tognin et al. 2015) However, studies often involve small sample sizes, and with lack of power comes increased chance that any observed effect is a false positive.(Button, loannidis et al. 2013) Furthermore, uncorrected p-values are commonly employed, inflating the false positive rates (Bennett, Wolford et al. 2009) and making the studies difficult to interpret.

A further complexity of VBM was highlighted by a study(Popescu, Schoonheim et al. 2016) comparing detectable GM changes by different software packages- FSL(Smith, Zhang et al. 2002), FreeSurfer(Dale, Fischl et al. 1999, Fischl, Sereno et al. 1999), SPM (Statistical Parametric Mapping Functional Imaging Laboratory, University College London, London, UK). The study examined agreement between these packages by using an MS cohort with a common disease type, a comparable disease duration, and controls that were matched. The study conducted by Popescu and colleagues(Popescu, Schoonheim et al. 2016) investigated the consistency in measurements of volume along with discrimination between patients and controls and, consistency of correlations with cognition. Consistency in volumes of GM regions was evaluated with Intraclass Correlation Coefficient (ICC) (consistency) for the lobar GM and deep GM (DGM) volume. The authors observed pronounced differences between the packages. The volume measurement consistency was substandard with a wide range of ICC values and, the lowest 
bioRxiv preprint doi: https://doi.org/10.1101/2020.04.11.036954; this version posted April 13,2020 . The copyright holder for this preprint (which was not certified by peer review) is the author/funder, who has granted bioRxiv a license to display the preprint in perpetuity. It is made available under aCC-BY-NC-ND 4.0 International license.

agreement structures included the amygdala, hippocampus, insula, and nucleus accumbens. Low ICC values signified potential reliability problems in relations with clinical variables as confirmed by inconstant results across methods. Nevertheless, good agreement was found between FreeSurfer and SPM in case of all cortical regions, with an ICC value of $>0.7$ for all, except left occipital lobe.

The deep GM (DGM) structure with high agreement in case of all methods was found to be the bilateral caudate nucleus. For bilateral thalamus, high agreement was observed between FSL and FreeSurfer. The DGM structures that include- bilateral thalamus, caudate nucleus, putamen, hippocampus and amygdala were found to have a significant difference between MS patients and controls in case of all methods.

Given the problems with single studies, there is potential for meta-analyses to reveal which of the observed effects are most likely to indicate common MS specific GM changes. In the absence of the original images, a coordinate based meta-analysis (CBMA) is possible using only the summary reports (coordinates and $Z$ scores) tabulated in the large majority of VBM publications. The approach utilises the scientific necessity that any true and generalisable effect must be repeatably observable. The null hypothesis of CBMA is that the reported coordinates are randomly distributed, which reflects the spatial distribution of false positive observations in VBM.(Scarpazza, Tognin et al. 2015)

Coordinates that are concordant across multiple studies are an unlikely chance occurrence and so are critical of the null and declared significant.

The primary aim of this meta-analysis was to determine the locations of consistent GM changes in in MS and CIS patients by means of a coordinate based random effect size (CBRES) (Tench, Tanasescu et al. 2017) meta-analysis. This algorithm clusters the reported coordinates where there is spatial concordance, then performs conventional random effect meta-analysis, of the reported $Z$ scores, in each cluster. The method has the advantage that censoring of effects due to the reporting of only summary results, rather than whole brain results, is dealt with statistically. Furthermore, CBRES offers principled control of the type 1 errors using the easily interpretable FCDR, which is based on the well-known FDR algorithm; FCDR is less conservative than the family-wise error rate (FWER) offered by other algorithms like activation likelihood estimation (ALE)(Laird, Fox et al. 2005) and multi-level kernel density analysis (MKDA)(Wager, Lindquist et al. 2009). Secondary analyses involving subgroup analysis and meta-regression are also performed using CBRES. In line with the suggestions of the preferred reporting items for systematic reviews and meta-analyses, the Royal Statistical Society, the coordinate data used in this analysis is provided as a supplement for validation purposes.

\section{Methods:}

\section{Search strategies}

A literature search was conducted using PubMed - with the following search term combinations("multiple sclerosis"[All Fields] OR "ms"[All Fields] OR CIS[All Fields] OR "clinically isolated syndrome"[All Fields]) AND ("voxel based morphometry"[All Fields] OR VBM[All Fields]) AND ("atrophy"[MeSH Terms] OR "atrophy"[All Fields]) AND ("grey matter"[All Fields] OR "gray matter"[All Fields] OR GM[All Fields]), Web of science, using the following search termsTS=("multiple sclerosis" OR MS OR CIS OR "clinically isolated syndrome") AND TS=("voxel based morphometry" OR VBM) AND TS=(atrophy) AND TS=("grey matter" OR "gray matter" OR GM) and Science direct, using the following search terms- TITLE-ABSTR-KEY("multiple sclerosis" OR MS OR "clinically isolated syndrome" OR CIS) and TITLE-ABSTR-KEY("voxel based morphometry" OR VBM) and TITLE-ABSTR-KEY("grey matter" OR "gray matter" OR GM) and 
bioRxiv preprint doi: https://doi org/10.1101/2020.04.11.036954; this version posted April $13,2020$. The copyright holder for this preprint (which was not certified by peer review) is the author/funder, who has granted bioRxiv a license to display the preprint in perpetuity. It is made available under aCC-BY-NC-ND 4.0 International license.

TITLE-ABSTR-KEY(atrophy). The studies included in our meta-analysis were conducted between 2006 and 2017.

\section{Study selection}

The articles have been reviewed on the basis of stringent inclusion and exclusion criteria. A study was considered for inclusion if it (a) involved participants with MS or CIS (Table 1) (b) compared patients to healthy controls (c) performed whole brain VBM for assessing GM atrophy (d) reported coordinates for GM volume changes in either Talairach (Talairach 1988) or Montreal Neurological Institute $(\mathrm{MNI})$ reference space.

Exclusions were made due to unreported coordinates or unavailable full text. Two independent researchers assessed these criteria of the individual studies and the MNI or Talairach coordinates. Any disagreements between the researchers were agreed on by consulting and discussing the respective original article.

\section{Study properties}

For each included study the following information is required for CBRES analysis: the censoring threshold i.e. the smallest $Z$ value the study considered as significant, the reported coordinates, and either the $Z$ score, estimated degrees of freedom and $t$ statistic, or uncorrected $p$-value; $t$ statistics and uncorrected $p$-values are converted automatically to $Z$ scores. Where no censoring threshold is reported, CBRES takes the lowest reported $Z$ score as the threshold.

\section{Coordinate based random effect size Meta-analysis}

All CBRES analysis is performed using ClusterZ, a free to use application that is part of NeuRoi (https://www.nottingham.ac.uk/research/groups/clinicalneurology/neuroi.aspx).

Details about the algorithms incorporated into ClusterZ are presented in (Tench, Tanasescu et al. 2017), but a brief overview is provided here. In CBRES a clustering algorithm (DBSCAN)(Sander, Ester et al. 1998)- (density-based spatial clustering of applications with noise) is used to determine where the coordinates reported by multiple independent studies are spatially concordant (clustered). To achieve this a clustering distance (CD) is needed; coordinates must fall within this distance of each other to form clusters. The CD is analogous to the full width half max (FWHM) in kernel based CBMA methods such as ALE and MKDA, but importantly it automatically adapts to the data to prevent increasing false positives as the number of studies increases.(Tench, Tanasescu et al. 2014) Once clusters are formed the reported Z scores are converted to standardised effect sizes by dividing by the square root of the number of subjects. Finally, a conventional random effect meta-analysis of these effect sizes is performed in each cluster. Where a study does not report a coordinate within a cluster, or where no effect sizes are reported by a study, the contribution of the study to the cluster is estimated using the censoring threshold.(Tench, Tanasescu et al. 2017)

The significant results of the CBRES meta-analysis are clusters of reported coordinates where the estimated effect size is statistically different to zero after controlling the false cluster discovery rate. This method of type 1 error control is based on FDR(Benjamini and Hochberg 1995), and works at the cluster level. The interpretation is that the expected proportion of clusters incorrectly declared significant (type 1 error) is controlled at a user specified level (usually $5 \%$ ). These clusters indicate both spatial and effect size concordance across the multiple studies. Such concordance is an unlikely chance event, suggesting that atrophy at the location of the clusters is a consistent feature of MS. A feature of CBRES is that the clusters declared significant can be 
found as a function of FCDR. This means that the next most significant clusters are flagged, and any that just miss the threshold for significance can be explored.

ClusterZ also performs other types of analyses. A sub analysis can be performed on subgroups of studies. This estimates a subgroup specific effect size in each of the clusters found significant during the full analysis (using all studies); this is useful since clusters may not be significant if the subgroup is small, yet the effect size might be of interest.

Furthermore, the use of standardised effect sizes makes meta-regression possible. This analysis looks for significant correlation between a specified covariate and the standardised effect size in each cluster. Covariates can be continuous, such as age, or dichotomous to allow comparison of two independent groups. Meta-regression can be performed independently of the meta-analysis, or post-hoc only within clusters found to be significant during the meta-analysis.

\section{Experimental Procedure}

Multiple experiments reported on the same subjects were pooled into single independent experiments. This prevents correlated results generated by the same subjects inducing apparent concordance that is not due to a generalizable MS process. (Turkeltaub, Eickhoff et al. 2012)

All planned analyses were performed controlling the FCDR at 0.05 . For each the next most significant clusters were explored, and reported, to make sure that none had just been missed at this threshold.

\section{Main analysis}

The main meta-analysis was performed using all studies meeting the inclusion criteria.

\section{Subanalyses}

Subanalyses for CIS, benign MS (BMS) $\{30\}$, Relapsing Remitting MS (RRMS), Primary Progressive MS (PPMS) and Secondary Progressive MS (SPMS) studies were. This analysis estimates effects of just the respective subgroup within significant clusters discovered using all studies.

\section{Meta-regression}

Post hoc regression analyses were performed for covariates that might influence the grey matter volume: mean age (years), MS disease duration (years; excluding CIS studies with no MS disease duration), MSFC, and EDSS (all studies and including RRMS studies only).

\section{Results:}

\section{Included studies and sample characteristics}

The literature search yielded 237 potential studies from which 34 met the inclusion criteria (Figure 1). The 34 included research papers reported 44 whole brain VBM experiments comparing MS subtypes and controls. (Table 1) 
bioRxiv preprint doi: https://doi.org/10.1101/2020.04.11.036954; this version posted April 13, 2020. The copyright holder for this preprint (which was not certified by peer review) is the author/funder, who has granted bioRxiv a license to display the preprint in perpetuity. It is made available under aCC-BY-NC-ND 4.0 International license.

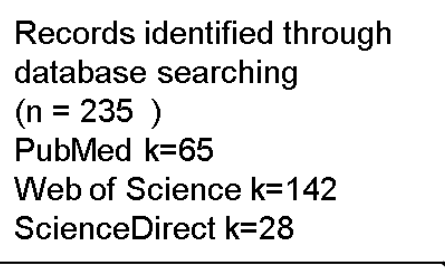

gh

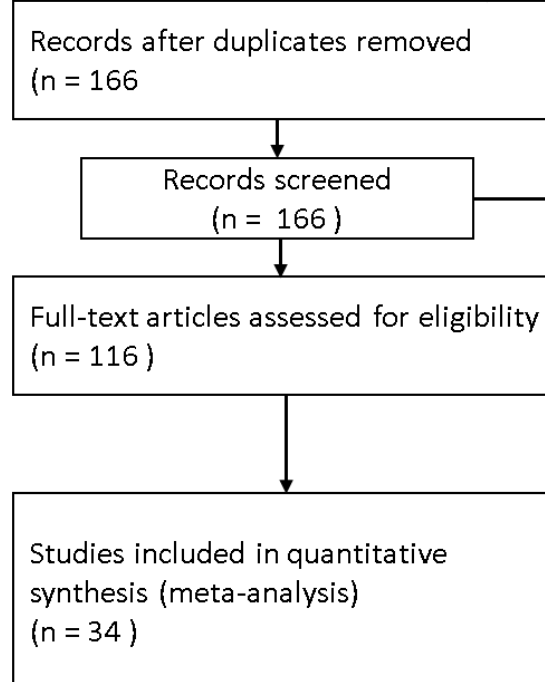

Records excluded

$(n=50)$

-full text unavailable $k=4$ -not Multiple Sclerosis study $k=41$ -reviews $k=5$

Full -text articles excluded, with reasons ( $n=82$ )

-White Matter coordinates $k=4$

-Controls not included $k=26$

-longitudinal study $k=12$

-no coordinates $k=11$

$-\mathrm{ROI} k=6$

-not voxel based morphometry study $k=23$

Figure 1: PRISMA flowchart(Liberati, Altman et al. 2009) showing the inclusion of studies in the meta-analysis and reasons for exclusion of studies.

The studies included in our meta-analysis were conducted between 2006 and 2017 and involved a total of 1561 patients and 1182 controls. The mean age of the patients was 40.49 years $(S D=$ 5.64). The patients and controls were matched for age and gender in 21 out of 44 included studies. They were also matched for age only, in 3 studies, and males and females have been matched for age in 2 studies. The number of controls varied in size from 9 to 90 and patients varied from 9 to 249. All included studies reported the mean or median age, EDSS and disease duration. The mean (standard deviation (SD)) EDSS was calculated to be 2.71 (1.54). The mean disease duration was 9.26 years (6.51). One study including CIS or RRMS participants by Muhlau(Muhlau, Buck et al. 2013) did not report the disease duration.

Across the studies, the minimum duration of disease, excluding the CIS studies, was 1.66 years and maximum was 30.50 years.

\begin{tabular}{|c|c|c|c|c|c|c|c|}
\hline & \multicolumn{2}{|c|}{ CONTROLS } & \multicolumn{3}{|l|}{ PATIENTS } & \multicolumn{2}{|c|}{$\begin{array}{c}\text { CLINICAL } \\
\text { CHARACTERISTICS OF MS } \\
\text { PARTICIPANTS }\end{array}$} \\
\hline STUDY & $\mathbf{N}$ & AGE & SUBTYPE & $\mathbf{N}$ & AGE & $\begin{array}{l}\text { DISEASE } \\
\text { DURATION } \\
(y)\end{array}$ & EDSS \\
\hline $\begin{array}{l}\text { (Audoin, } \\
\text { Davies et al. } \\
\text { 2006) }\end{array}$ & 10 & $37(31-52)$ & $\begin{array}{l}\text { EARLY RRMS(Audoin, Davies et al. } \\
\text { 2006) }\end{array}$ & 21 & $36(27-55)$ & $2.15(1.2-3.8)$ & $1(0-3)$ \\
\hline $\begin{array}{l}\text { (Audoin, } \\
\text { Zaaraoui et al. } \\
\text { 2010) }\end{array}$ & 37 & $28(8)$ & CIS(Polman, Reingold et al. 2005) & 62 & $29(20-46)$ & 0.33 & $1(0-3.5)$ \\
\hline $\begin{array}{c}\text { (Baltruschat, } \\
\text { Ventura- }\end{array}$ & 15 & $30.47(5.91)$ & RRMS(Polman, Reingold et al. 2005) & 17 & $32.82(6.41)$ & $4.53(3.5)$ & $2.24(1.09)$ \\
\hline
\end{tabular}


bioRxiv preprint doi https://doi.org/10.1101/2020 04.11 .036954 ; this version posted April $13,2020$. The copyright holder for this preprint (which was not certified by peer review) is the author/funder, who has granted bioRxiv a license to display the preprint in perpetuity. It is made available under aCC-BY-NC-ND 4.0 International license.

\begin{tabular}{|c|c|c|c|c|c|c|c|}
\hline $\begin{array}{l}\text { Campos et al. } \\
\text { 2015) }\end{array}$ & & & & & & & \\
\hline $\begin{array}{l}\text { (Bisecco, } \\
\text { Stamenova et } \\
\text { al. 2018) }\end{array}$ & 52 & $37.3(13.1)$ & RRMS(Polman, Reingold et al. 2011) & 125 & $36.8(10.7)$ & $9.6(8.7)$ & $2(0-6)$ \\
\hline $\begin{array}{l}\text { (Bodini, } \\
\text { Khaleeli et al. } \\
\text { 2009) }\end{array}$ & 23 & $35.1(7.9)$ & $\begin{array}{c}\text { EARLY PPMS(Thompson, Montalban } \\
\text { et al. 2000) }\end{array}$ & 36 & $44.8(11.13)$ & $3.3(0.9)$ & $4.5(1.5-7)$ \\
\hline \multirow{2}{*}{$\begin{array}{l}\text { (Bonavita, } \\
\text { Gallo et al. } \\
\text { 2011) }\end{array}$} & \multirow{2}{*}{18} & \multirow{2}{*}{$39(10)$} & \multirow{2}{*}{ RRMS(Polman, Reingold et al. 2005) } & \multirow{2}{*}{36} & $\begin{array}{l}\text { Cognitively } \\
\text { Impaired (Cl)- } \\
40.9(8.7)\end{array}$ & $11.86(7.08)$ & $2.8(1.1)$ \\
\hline & & & & & $\begin{array}{l}\text { Cognitively } \\
\text { Preserved } \\
\text { (CP)- 40.5(6.9) }\end{array}$ & 10.91(4.67) & $2.6(1.7)$ \\
\hline $\begin{array}{l}\text { (Ceccarelli, } \\
\text { Rocca et al. } \\
2008)\end{array}$ & 21 & $40.9(24-62)$ & CIS(Lublin and Reingold 1996) & 28 & $30.7(21-43)$ & 0 & $0(0-1)$ \\
\hline \multirow{2}{*}{$\begin{array}{l}\text { (Ceccarelli, } \\
\text { Rocca et al. } \\
\text { 2008) }\end{array}$} & \multirow{2}{*}{20} & \multirow{2}{*}{$36.8(6.8)$} & BMS(Lublin and Reingold 1996) & 19 & $41.5(5.6)$ & $20(15-30)$ & $2(1-3)$ \\
\hline & & & RRMS(Lublin and Reingold 1996) & 15 & $33.3(7.8)$ & $6(2-10)$ & $1.5(1-3.5)$ \\
\hline $\begin{array}{l}\text { (Ceccarelli, } \\
\text { Rocca et al. } \\
2009 \text { ) }\end{array}$ & 17 & $51.3(26-68)$ & PPMS(Polman, Reingold et al. 2005) & 18 & $49.6(38.73)$ & $10.7(4-21)$ & $5.5(3-7)$ \\
\hline \multirow{2}{*}{$\begin{array}{c}\text { (Cerasa, } \\
\text { Valentino et al. } \\
\text { 2013) }\end{array}$} & \multirow{2}{*}{20} & \multirow{2}{*}{$36.9(5.8)$} & $\begin{array}{c}\text { RRMS without cerebellar } \\
\text { symptoms(Polman, Reingold et al. } \\
\text { 2005) }\end{array}$ & 14 & $38.6(8.5)$ & $8.8(4.4)$ & $2(1.5-4.5)$ \\
\hline & & & $\begin{array}{c}\text { RRMS with cerebellar } \\
\text { symptoms(Polman, Reingold et al. } \\
\text { 2005) }\end{array}$ & 12 & $38.9(8.7)$ & $12.1(8.7)$ & $2.5(1-4)$ \\
\hline $\begin{array}{l}\text { (Debernard, } \\
\text { Melzer et al. } \\
\text { 2014) }\end{array}$ & 25 & $35.2(10.3)$ & $\begin{array}{l}\text { EARLY RRMS(Polman, Reingold et al. } \\
\text { 2011) }\end{array}$ & 25 & $37.2(8.6)$ & $2.4(1.5)$ & $1.5(0-4.5)$ \\
\hline $\begin{array}{l}\text { (Eshaghi, } \\
\text { Bodini et al. } \\
\text { 2014) }\end{array}$ & 19 & $\begin{array}{c}37.6(34.4 \\
41.9)\end{array}$ & $\begin{array}{l}\text { PPMS(Thompson, Montalban et al. } \\
\text { 2000) }\end{array}$ & 36 & $\begin{array}{l}42.8(39.4 \\
46.6)\end{array}$ & $3.3(2.9,3.6)$ & $4(1.5,7)$ \\
\hline $\begin{array}{c}\text { (Gallo, } \\
\text { Esposito et al. } \\
\text { 2012) } \\
\end{array}$ & 15 & $36.3(20-53)$ & RRMS(Polman, Reingold et al. 2005) & 30 & $35.9(19-51)$ & $9.2(3-22)$ & $2.1(1-5.5)$ \\
\hline $\begin{array}{l}\text { (Gobbi, Rocca } \\
\text { et al. 2014) }\end{array}$ & 90 & $39.7(13.7)$ & MIXED_MS & 123 & $41.7(10.3)$ & $12.6(1-44)$ & $2(0-7)$ \\
\hline \multirow{2}{*}{$\begin{array}{l}\text { (Gomez, } \\
\text { Campos et al. } \\
\text { 2013) }\end{array}$} & \multirow{2}{*}{18} & \multirow{2}{*}{$31.06(5.67)$} & $\begin{array}{l}\text { RRMS Fatigue(Polman, Reingold et } \\
\text { al. 2011) }\end{array}$ & 32 & $37.72(5.9)$ & $7.44(5.15)$ & $3.2(1.68)$ \\
\hline & & & $\begin{array}{l}\text { RRMS not fatigued(Polman, } \\
\text { Reingold et al. 2011) }\end{array}$ & 28 & $34.96(5.87)$ & $5.14(3.69)$ & $1.96(1.2)$ \\
\hline $\begin{array}{l}\text { (Henry, Shieh } \\
\text { et al. 2008) }\end{array}$ & 49 & $38(11)$ & CIS(Anderson, Fernando et al. 2007) & 41 & $37(10)$ & $0.3(0.25)$ & $1.1(0.8)$ \\
\hline $\begin{array}{l}\text { (Khaleeli, } \\
\text { Cereignani et } \\
\text { al. 2007) }\end{array}$ & 23 & $35.1(23-56)$ & EARLY PPMS(Thompson 2004) & 46 & $43.5(19-65)$ & $3.3(2-5)$ & $4.5(1.5-7)$ \\
\hline $\begin{array}{l}\text { (Lin, Chen et } \\
\text { al. 2013) }\end{array}$ & 11 & $39.5(13.2)$ & RRMS(Polman, Reingold et al. 2011) & 11 & $38.5(12.2)$ & $30.5(11.1)$ & $3.4(2.3)$ \\
\hline $\begin{array}{l}\text { (Mesaros, } \\
\text { Rovaris et al. } \\
\text { 2008) }\end{array}$ & 21 & $45.7(25-66)$ & $\begin{array}{c}\text { BMS [Criteria for a diagnosis } \\
\text { ofBMSwere anEDSSscore } \\
\text { of } 3.0 \text { or less and a disease duration } \\
\text { of } 15 \text { years or more.] }\end{array}$ & 60 & $46.2(35-63)$ & $22.7(15-40)$ & $1.5(0-3)$ \\
\hline
\end{tabular}


bioRxiv preprint doi: https://doi.org/10.1101/2020.04.11.036954; this version posted April 13, 2020. The copyright holder for this preprint (which was not certified by peer review) is the author/funder, who has granted bioRxiv a license to display the preprint in perpetuity. It is made available under aCC-BY-NC-ND 4.0 International license.

\begin{tabular}{|c|c|c|c|c|c|c|c|}
\hline $\begin{array}{l}\text { (Mesaros, } \\
\text { Rovaris et al. } \\
\text { 2008) }\end{array}$ & 21 & $45.7(25-66)$ & SPMS(Lublin and Reingold 1996) & 35 & $46.5(30-63)$ & $16.2(7-27)$ & $6(4-7)$ \\
\hline \multirow{2}{*}{$\begin{array}{l}\text { (Morgen, } \\
\text { Sammer et al. } \\
\text { 2006) }\end{array}$} & \multirow{2}{*}{19} & \multirow{2}{*}{$31.7(7.5)$} & $\begin{array}{l}\text { RRMS(McDonald, Compston et al. } \\
\text { 2001) }\end{array}$ & 19 & $33.05(8.26)$ & $1.66(1.43)$ & $1(0-3.5)$ \\
\hline & & & $\begin{array}{l}\text { RRMS low PASAT(McDonald, } \\
\text { Compston et al. 2001) }\end{array}$ & 10 & $36.7(8.05)$ & $2.0(1.78)$ & $2(0-3.5)$ \\
\hline $\begin{array}{l}\text { (Muhlau, Buck } \\
\text { et al. 2013) }\end{array}$ & 49 & $36.4(13)$ & $\begin{array}{l}\text { CIS- } \\
\text { CIS was defined as one clinical event } \\
\text { suggestive of demyelination and at } \\
\text { least } 2 \text { clinically-silent cerebral } \\
\text { WMLs that are compatible with } \\
\text { RRMS, and are at least } 3 \mathrm{~mm} \text { in } \\
\text { diameter or RRMS(Polman, } \\
\text { Reingold et al. 2005) }\end{array}$ & 249 & $36.8(10.7)$ & - & 1.4(1) \\
\hline \multirow{2}{*}{$\begin{array}{l}\text { (Parisi, Rocca } \\
\text { et al. 2014) }\end{array}$} & \multirow{2}{*}{9} & \multirow{2}{*}{$54.4(12.1)$} & Classical MS & 9 & $50.2(11)$ & $14(4-20)$ & $3(1.5-6)$ \\
\hline & & & Cortical MS(Zarei 2006) & 9 & 48.9(9.9) & $8(2-31)$ & $4(1-6)$ \\
\hline $\begin{array}{c}\text { (Prinster, } \\
\text { Quarantelli et } \\
\text { al. 2006) }\end{array}$ & 34 & $43.2(13.2)$ & RRMS(Poser, Paty et al. 1983) & 51 & $38.6(7.5)$ & $13.1(6.4)$ & $\begin{array}{c}2.6(1.5- \\
4.5)\end{array}$ \\
\hline $\begin{array}{l}\text { (Prakash, } \\
\text { Snook et al. } \\
\text { 2010) }\end{array}$ & 15 & $45.8(1.8)$ & RRMS(Poser, Paty et al. 1983) & 21 & $44.2(1.9)$ & $7.3(0.1)$ & $2.2(0-6)$ \\
\hline $\begin{array}{l}\text { (Riccitelli, } \\
\text { Rocca et al. } \\
\text { 2012) }\end{array}$ & 88 & $39.7(18-65)$ & RRMS(Lublin and Reingold 1996) & 78 & $40.2(20-63)$ & $10(1-28)$ & $1.5(1-4.5)$ \\
\hline \multirow{2}{*}{$\begin{array}{l}\text { (Riccitelli, } \\
\text { Rocca et al. } \\
\text { 2011) }\end{array}$} & \multirow{2}{*}{14} & \multirow{2}{*}{$38.7(8.4)$} & $\begin{array}{l}\text { RRMS Fatigue(Lublin and Reingold } \\
\text { 1996) }\end{array}$ & 10 & $38(7.7)$ & $8.2(6.2)$ & $1.5(1.5-2)$ \\
\hline & & & $\begin{array}{l}\text { RRMS not fatigued(Lublin and } \\
\text { Reingold 1996) }\end{array}$ & 14 & $38.6(8.5)$ & $10.6(6.6)$ & $1.5(0-1.5)$ \\
\hline \multirow{2}{*}{$\begin{array}{l}\text { (Sanchis- } \\
\text { Segura, Cruz- } \\
\text { Gomez et al. } \\
\text { 2016) }\end{array}$} & 35 & $25.54(5.35)$ & RRMS male & 22 & $38.68(8.72)$ & $6.45(5.53)$ & $2.5(0-6.5)$ \\
\hline & 28 & $27.96(7.85)$ & RRMS female & 34 & 40.85(10.18) & $8.82(7.47)$ & $\begin{array}{l}2.38(0- \\
6.5)\end{array}$ \\
\hline $\begin{array}{c}\text { (Sepulcre, } \\
\text { Sastre-Garriga } \\
\text { et al. 2006) }\end{array}$ & 15 & $43.2(10.9)$ & $\begin{array}{l}\text { PPMS(Thompson, Montalban et al. } \\
\text { 2000) }\end{array}$ & 31 & $43.7(9.87)$ & $3(2-5)$ & $4.5(3.5-7)$ \\
\hline $\begin{array}{c}\text { (Spano, } \\
\text { Cercignani et } \\
\text { al. 2010) }\end{array}$ & 20 & $40.5(11.07)$ & $\begin{array}{l}\text { BMS(McDonald, Compston et al. } \\
\text { 2001) }\end{array}$ & 10 & $44.5(6.5)$ & $17.1(4.5)$ & $1.75(1-3)$ \\
\hline $\begin{array}{c}\text { (Tavazzi, } \\
\text { Laganà et al. } \\
\text { 2015) } \\
\end{array}$ & 31 & $47.9(14.5)$ & $\begin{array}{l}\text { PPMS(McDonald, Compston et al. } \\
\text { 2001) }\end{array}$ & 18 & $46.9(8.1)$ & $12.4(7.73)$ & $6(3-8)$ \\
\hline \multirow{3}{*}{$\begin{array}{l}\text { (van de Pavert, } \\
\text { Muhlert et al. } \\
\text { 2016) }\end{array}$} & \multirow{3}{*}{30} & \multirow{3}{*}{$37.8(11.8)$} & PPMS(Polman, Reingold et al. 2011) & 25 & $52.5(9.8)$ & $12(7.4)$ & $6(0-6.5)$ \\
\hline & & & RRMS(Polman, Reingold et al. 2011) & 30 & $42.5(9.6)$ & $11.5(10.5)$ & $\begin{array}{l}1.75(1- \\
6.5)\end{array}$ \\
\hline & & & SPMS(Polman, Reingold et al. 2011) & 25 & $52.8(7.6)$ & $24(8.2)$ & $\begin{array}{l}6.5(4.5- \\
8.5)\end{array}$ \\
\hline $\begin{array}{l}\text { (Zhang, Zhang } \\
\text { et al. 2016) }\end{array}$ & 29 & 37.79(10.29) & RRMS(Polman, Reingold et al. 2011) & 39 & $38.26(9.05)$ & $7.69(5.96)$ & $2.24(1.58)$ \\
\hline
\end{tabular}


bioRxiv preprint doi: https://doi.org/10.1101/2020.04.11.036954; this version posted April $13,2020$. The copyright holder for this preprint (which was not certified by peer review) is the author/funder, who has granted bioRxiv a license to display the preprint in perpetuity. It is made available under aCC-BY-NC-ND 4.0 International license.

\begin{tabular}{|c|c|c|c|c|c|c|}
\hline $\begin{array}{c}\text { (Doche, Lecocq } \\
\text { et al. 2017) }\end{array}$ & 16 & 37.1(10.2) & RRMS(Polman, Reingold et al. 2011) & 23 & $34.2(9.3)$ & $4.5(4.6)$ \\
\hline $\begin{array}{c}\text { (Weygandt, } \\
\begin{array}{c}\text { Wakonig et al. } \\
\text { 2018) }\end{array}\end{array}$ & 21 & 49.1 & HI-LB MS(Polman, Reingold et al. & 18 & $49.8(7.7)$ & $11.7(7.2)$ \\
\hline
\end{tabular}

Table 1: Demographics and clinical characteristics of datasets for studies included in the meta-analysis.

\section{Primary meta-analysis}

Analysis included 44 experiments and found 8 significant clusters. The location of significant clusters involved basal ganglia and cortical regions. The effect sizes of the clusters found using all studies are given in Table 3. The significant clusters and forest plots are shown in Figure 2 and Figure 3. The first non-significant cluster was at a FCDR of 0.12 .

\section{Subanalyses}

Results from the subanalysis are shown in table 3. It shows estimated effects sizes considering only the respective subgroup within each of the clusters from the primary meta-analysis. It is apparent that the estimated effect has the largest magnitude in the SPMS group.

\begin{tabular}{|c|c|c|c|c|c|c|c|c|}
\hline$\#$ & Cluster & $\begin{array}{c}\text { Talairach } \\
\text { coordinates }\end{array}$ & $\begin{array}{c}\text { Main analysis } \\
\text { Mean (SD); } \\
\text { FCDR } \\
\end{array}$ & $\begin{array}{c}\text { CIS } \\
\text { subanalysis } \\
\text { Mean (SD) }\end{array}$ & $\begin{array}{c}\text { BMS } \\
\text { subanalysis } \\
\text { Mean (SD) } \\
\end{array}$ & $\begin{array}{c}\text { RRMS } \\
\text { subanalysis } \\
\text { Mean (SD) } \\
\end{array}$ & $\begin{array}{c}\text { PPMS } \\
\text { subanalysis } \\
\text { Mean (SD) } \\
\end{array}$ & $\begin{array}{c}\text { SPMS } \\
\text { subanalysis } \\
\text { Mean (SD) }\end{array}$ \\
\hline 1 & \begin{tabular}{|c|} 
Right \\
Thalamus \\
\end{tabular} & $\begin{array}{c}(10.0-30.0 \\
7.0)\end{array}$ & $\begin{array}{c}-1.18 \\
(0.36) ; \mathbf{0 . 0 0 0 2 5} \\
\end{array}$ & $-1.09(0.12)$ & $-1.75(0.01)$ & $-1.08(0.36)$ & $-0.82(0.41)$ & $-1.73(0.01)$ \\
\hline 2 & $\begin{array}{c}\text { Left } \\
\text { Thalamus } \\
\end{array}$ & $\begin{array}{c}(-14.3-28.3 \\
10.4) \\
\end{array}$ & $\begin{array}{c}-1.17 \\
(0.32) ; \mathbf{0 . 0 0 0 2 5} \\
\end{array}$ & $-1.1(0.17)$ & $-1.7(0.01)$ & $-1.12(0.28)$ & $-0.82(0.48)$ & $-1.7(0.01)$ \\
\hline 3 & \begin{tabular}{|c|} 
Left \\
Putamen
\end{tabular} & $\begin{array}{cc}(-26.0 & 6.0 \\
5.0) & \\
\end{array}$ & $\begin{array}{c}-0.75 \\
(0.41) ; \mathbf{0 . 0 0 0 2 5} \\
\end{array}$ & $-0.65(0.39)$ & $-1.29(0.13)$ & $-0.63(0.3)$ & $-0.66(0.51)$ & $-1.52(0.01)$ \\
\hline 4 & \begin{tabular}{|c|} 
Right \\
Postcentral \\
Gyrus BA3 \\
\end{tabular} & $\begin{array}{c}(36.9-26.1 \\
49.0) \\
\end{array}$ & $\begin{array}{c}-0.74 \\
(0.33) ; 0.01 \\
\end{array}$ & 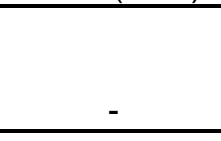 & $-1.18(0.01)$ & $-0.82(0.01)$ & $-0.56(0.53)$ & $-1.3(0.01)$ \\
\hline 5 & $\begin{array}{l}\text { Right } \\
\text { Insula } \\
\text { BA13 }\end{array}$ & $\begin{array}{c}(37.2-18.5 \\
13.6)\end{array}$ & $\begin{array}{c}-0.58 \\
(0.3) ; 0.01\end{array}$ & - & - & $-0.7(0.16)$ & $-0.5(0.36)$ & $-1.11(0.01)$ \\
\hline 6 & \begin{tabular}{|c|} 
Left \\
Postcentral \\
Gyrus BA3 \\
\end{tabular} & $\begin{array}{c}(-51.0-19.0 \\
37.8) \\
\end{array}$ & $\begin{array}{c}-0.66 \\
(0.4) ; 0.01 \\
\end{array}$ & - & $-1.22(0.01)$ & $-0.69(0.01)$ & $-0.68(0.54)$ & $-1.31(0.01)$ \\
\hline 7 & \begin{tabular}{|c|} 
Left \\
Superior \\
Temporal \\
Gyrus \\
\end{tabular} & $\begin{array}{c}(-47.9-20.9 \\
2.5) \\
\end{array}$ & $\begin{array}{c}-0.68 \\
(0.14) ; 0.01 \\
\end{array}$ & - & - & $-0.68(0.2)$ & - & - \\
\hline 8 & $\begin{array}{l}\text { Right } \\
\text { Caudate } \\
\text { Body }\end{array}$ & $\begin{array}{c}\left(\begin{array}{c}11.9 \\
20.2)\end{array}\right. \\
\end{array}$ & $\begin{array}{c}-0.57 \\
(0.46) ; 0.01\end{array}$ & - & $-0.99(0.01)$ & $-0.37(0.37)$ & $-0.45(0.47)$ & $-1.46(0.01)$ \\
\hline
\end{tabular}

Table 3: Table shows significant clusters for main analysis and estimated effects from the subanalyses. The column 'main analysis' shows effect size, standard deviation and p_value for each significant cluster. The following columns consist of effect size \pm standard deviation for the subanalyses; - signifies no contribution of the subgroup to the cluster. (BA = Brodmann Area) 


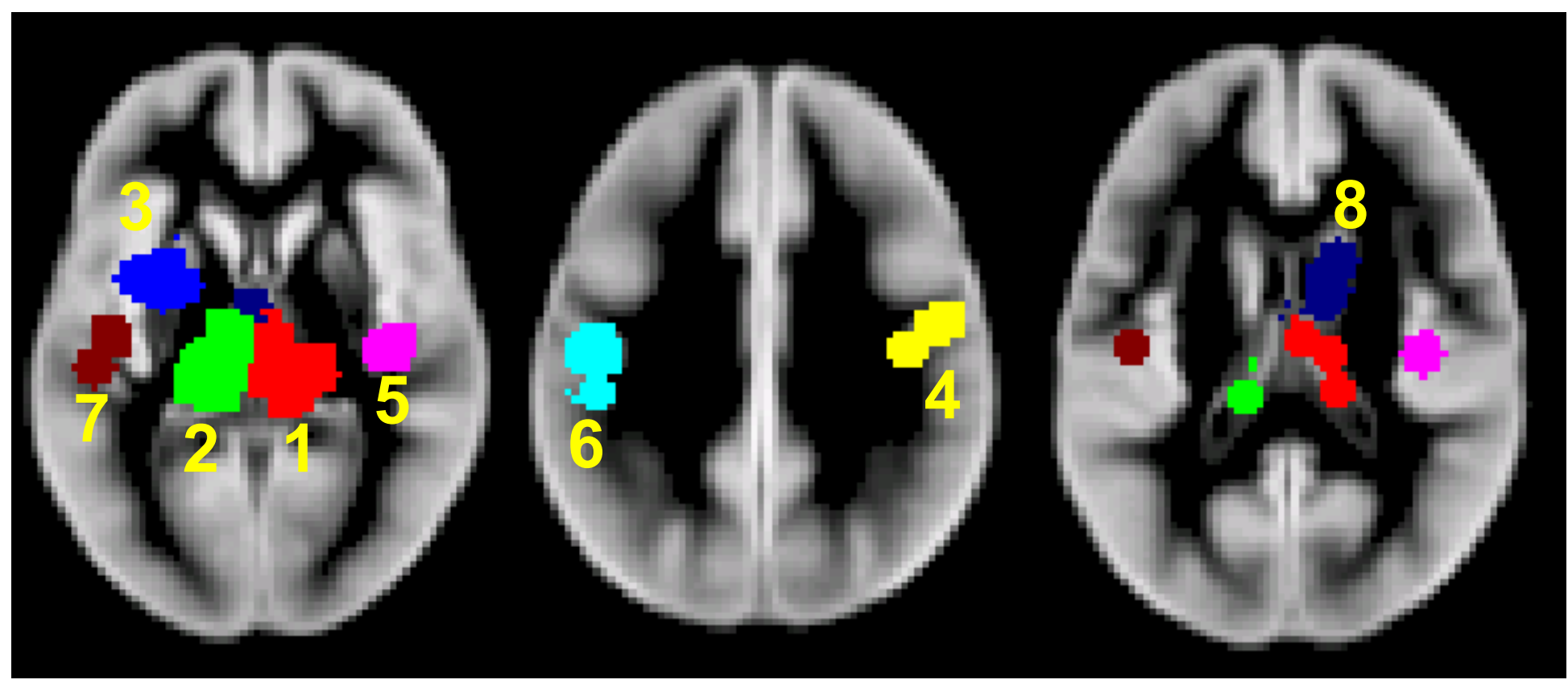

Figure 2: Significant clusters of GM atrophy reported by the 44 VBM experiments.1-Right Thalamus 2-Left Thalamus 3- Left Putamen 4-Right BA3 5- Right BA13 6- Left BA3 7-Left Superior Temporal Gyrus 8- Right Caudate Body (BA = Brodmann Area)

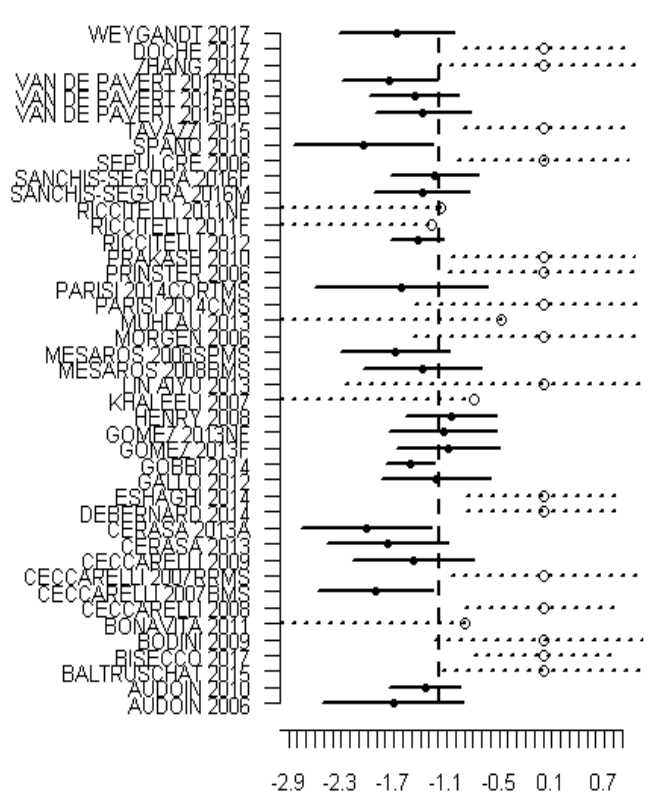

Effect Size

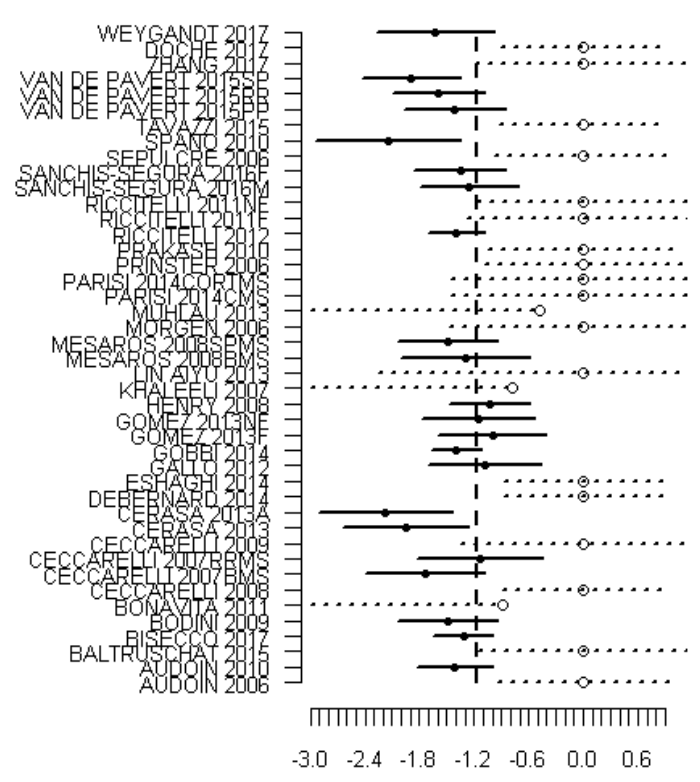

Effect Size

Figure 3: Forest Plots for the significant clusters (1 and 2) of GM atrophy reported by the 44 VBM experiments. Markers with solid circle indicate the effect size reported by the study in the respective cluster. The confidence intervals are depicted as solid horizontal lines spanning \pm 1.96 
times the within study standard deviation of the effect size. Censored values are depicted by open circle markers and the intervals by dashed lines $(\cdots 0 \cdots)$.

\section{Metaregression}

Age

ClusterZ found no clusters with age as a covariate. The first non-significant cluster was at FCDR 0.2 .

\section{MS Disease Duration}

Two clusters with significant correlation between MS disease duration were found and reported; table 3 (figure 2, Cluster 1 and Cluster 2). The first non-significant cluster was found to be at FCDR 0.07 that is, just beyond the threshold of 0.05 for significance.

\section{MSFC}

Regression analysis could not be performed because only 9 out of 44 studies have given MSFC for MS patients.

EDSS

ClusterZ found no significant clusters. The first non-significant cluster was found to be at FCDR 0.30 .

\section{EDSS (RRMS only)}

ClusterZ found no significant clusters. The first non-significant cluster was found to be at FCDR 0.25 .

\begin{tabular}{|c|c|c|c|c|}
\hline Cluster number & $\begin{array}{c}\text { Talairach } \\
\text { coordinates }\end{array}$ & p-value & Cov & $\begin{array}{c}\text { Percentage of } \\
\text { mean effect per } \\
\text { year }\end{array}$ \\
\hline 1 (Right Thalamus) & $\left(\begin{array}{lll}10.0 & -30.0 & 7.0\end{array}\right)$ & 0.01 & -0.06 & 5 \\
\hline 2 (Left Thalamus) & $\left(\begin{array}{lll}-14.3 & -28.3 & 10.4\end{array}\right)$ & 0.01 & -0.05 & 4 \\
\hline
\end{tabular}

Table 3: Significant clusters for MS Disease Duration Meta Regression in all studies (excluding 4 CIS studies). Cov = Regression coefficient; Cov refers to change in effect size for every 1 year of disease duration.

\section{Subgroup analysis}

Planned comparison of effect sizes between patient subgroups was limited due to small numbers of studies in each group. In particular, there were only two SPMS studies, so no comparisons were performed with this subgroup. For completeness, however, no differences were found when comparing RRMS and PPMS (first cluster was found to be at FCDR 0.5), RRMS and BMS (first cluster was found to be at FCDR 1), CIS and RRMS (first cluster was found to be at FCDR 1), PPMS and BMS (first cluster was found to be at FCDR 0.5). 


\section{Discussion}

A commonly held view of MS, previously, involved the picture of a multifocal and multi-phasic immune-mediated WM inflammatory demyelinating disorder, the suppression of which is the basis of progress in DMTs to date. Nevertheless, it is quite clear as of now that GM is extensively involved as well. The literature makes it clear that GM pathology exists in early RRMS increasing with time. Brain atrophy in MS, as monitored during life by MRI, possibly reflects neuro-axonal loss (although other factors that can affect brain tissue volumes should be borne in mind, especially when assessing short-term changes).

\section{GM atrophy in MS: a pathological stance}

GM tissue damage is an important pathological process in MS that underlies neurological disability.(Fisher, Lee et al. 2008) The loss of volume is the result of many dynamic processes, with a balance between destructive and reparative mechanisms with interaction among neurons, oligodendrocytes, axons, microglia, astrocytes, inflammatory cells, endothelial cells and water distribution. (Koskimäki, Bernard et al. 2018)

Previous literature shows differences in GM atrophy between MS subtypes involving a selective myriad of brain regions along with an increased extent of atrophy in common regions, such as the thalamus, in the progressive phase of the disease. (Gilmore, Donaldson et al. 2009) The reason of GM pathogenesis is not quite clear, however many suggestions regarding relevant pathological processes have been put forward, comprising meningeal inflammation and the secretion of myelinotoxic factors, retrograde myelino-axonal degradation, virtual hypoxia in neuronal mitochondria, Glutamate excitotoxicity, reduced availability of acetylcholine in the synaptic cleft, lymphoid tissue formation and antigenic variability in neuronal subpopulations. (Magliozzi, Howell et al. 2007, Geurts and Barkhof 2008, Trapp and Stys 2009, Klaver, De Vries et al. 2013, Stassart, Möbius et al. 2018) In addition, failure to control latent EBV infection in an immune privileged site, like the subarachnoid space could possibly result in recurrent intrathecal EBV reactivation and tissue damage in the surrounding GM regions. (Angelini, Serafini et al. 2013, Lossius, Johansen et al. 2014) Nevertheless, numerous other studies have been unsuccessful in detecting EBV in the MS brain lesions.(Willis, Stadelmann et al. 2009, Sargsyan, Shearer et al. 2010) and this remains to be an extremely debated controversy(Lassmann, Niedobitek et al. 2011).

Alternatively, there could be an involvement of an infectious agent in cortical demyelination and neuronal loss with primary tropism for oligodendrocytes and/or cortical neurons(Borkosky, Whitley et al. 2012), although no evidence exists yet for this likelihood in the disease. Further mechanisms targeting adaptive and/or innate immune responses to the GM include alterations, that are specifically linked to the function and/or degeneration of neurons, oligodendrocytes or astrocytes, such as metabolic changes(Zeis, Graumann et al. 2008), expression of post-translationally modified proteins and/or peptides(Mastronardi and Moscarello 2005), excitatory neurotransmitter release (Baranzini, Srinivasan et al. 2010), changes in electrical activity and/or ion currents and cytokine and/or cytokine receptor expression(Neumann, Cavalié et al. 1995).

\section{Regional GM atrophy in MS}

The thalamus has cortical, subcortical and cerebellar connections. Hence, it is known to be a critical node in networks that support cognitive functions, memory processes, executive functions including information processing and attention.(Fama and Sullivan 2015)

Recent imaging as well as pathology studies have demonstrated the involvement of thalamus even in early MS. Atrophy of the thalamus has been observed in early RRMS(Trapp, Peterson et al. 1998), CIS at presentation(Štecková, Hluštík et al. 2014) and pediatric MS(Haider, Simeonidou et al. 2014). The volume loss in thalamus is possibly due in part to disconnection created by WM lesions(Azevedo, Overton et al. 2015). There is also evidence of a relationship between thalamic volume and WM lesion volume within thalmocortical projections, utilising diffusion tensor imaging tractography.(Lassmann 2014) 
bioRxiv preprint doi: https://doi org/10.1101/2020.04.11.036954; this version posted April $13,2020$. The copyright holder for this preprint (which was not certified by peer review) is the author/funder, who has granted bioRxiv a license to display the preprint in perpetuity. It is made available under aCC-BY-NC-ND 4.0 International license.

Cifelli and colleagues(Cifelli, Arridge et al. 2002) conducted a study of normalised thalamic volume (NTV) measurements in SPMS patients. Volumes of manually outlined thalami were normalised by intracranial volumes and showed a mean decrease of $17 \%$. A moderate correlation was also observed third ventricular enlargement. According to the study conducted by Houtchens and colleagues(Houtchens, Benedict et al. 2007), the enlargement of third ventricle indicates a strong correlation with cognitive impairment in MS, indicating the clinical relevance of damage caused to the surrounding structures, such as the thalamus. Furthermore, the normalised thalamic volume was found to be $16.8 \%$ lower in the MS group as compared to healthy controls.

ClusterZ found a cluster in the left putamen with significant mean effect size of -0.75 . The putamen is a part of the dorsal striatum and the basal ganglia and, plays a role in the regulation of movement, coordination, motor function and cognition.(Henry, Shieh et al. 2008, Batista, Zivadinov et al. 2012, Modica, Zivadinov et al. 2015) It is also involved in modulation of sensory and motor aspects of pain.(Munakomi.) Thus, a pathology like, neurodegeneration, might be expected to cause a broad spectrum of clinical manifestation from motor dysfunction to variable psychiatric disorder. (Koikkalainen, Hirvonen et al. 2007, Uono, Sato et al. 2017)

There is involvement of the left putamen in language functions such as bilingual language processing (Abutalebi, Della Rosa et al. 2012) and production, with some authors debating about the functional segregation of anterior and posterior putamen(Oberhuber, Parker Jones et al. 2013).

Employing FMRIB's Integrated Registration \& Segmentation Tool (FIRST)(Patenaude, Smith et al. 2011) as a tool for segmentation, previous researches have demonstrated progressive atrophy of the putamen in RRMS and SPMS(Bergsland, Horakova et al. 2012). Kramer and colleagues(Kramer, Meuth et al. 2015) recently showed putamen atrophy and its longitudinal progress during the disease course in MS. The quantitative analysis of putamen volume relative to disease duration showed a significant reduction in MS patients as compared to healthy controls. However, our study did not find a correlation between putamen atrophy and MS disease duration.

ClusterZ identified clusters in the right and left postcentral gyri with significant mean effect sizes of -0.74 and -0.66 respectively for GM atrophy in MS or CIS. BA3 is an eminent gyrus in the primary somatosensory cortex that is the sensory receptive area for the sense of touch. $\mathrm{Li}$ et al (Li, Jewells et al. 2013) used diffusion tensor imaging (DTI) and demonstrated neuroconnectivity changes in the left postcentral gyrus and the putamen, along with other regions. The left postcentral gyrus showed reduced communicability correlating with the 25 -foot walk test results. Han and colleagues(Han, Tian et al. 2017) performed VBM analysis that revealed significant difference in GM between MS patients and controls. This decreased GM was observed in the right temporal lobe (caudate nucleus), right parietal lobe (postcentral gyrus) and right insula, along with other gyri, of RRMS patients which is partially consistent with our results.

ClusterZ revealed clusters in the left superior temporal gyrus with significant mean effect size of 0.68 . The superior temporal gyrus is associated with auditory and speech comprehension (Leff, Schofield et al. 2009, Friederici 2012) and perception of emotions in facial stimuli(Bigler, Mortensen et al. 2007, Radua, Phillips et al. 2010). In addition, it is an essential structure in the pathway containing prefrontal cortex and amygdala that are responsible for social cognition processes.(Bigler, Mortensen et al. 2007, Michl, Meindl et al. 2014) The study conducted by Achiron and colleagues (Achiron, Chapman et al. 2013), which compared RRMS patients and healthy controls, suggested correlation between reduced cortical thickness in superior temporal gyrus and global cognitive score, attention, information processing speed and motor skills.

ClusterZ revealed a cluster in the right insula with a significant effect size of -0.58 . Following the removal of the temporal lobe for treating drug-refractory seizures in epileptic patients, stimulation of the exposed inferior part of the insular cortex provoked a variety of visceral sensory and motor responses, as well as somatic sensory responses, especially in the face, tongue, and upper limbs. This underwrote the conception of the insula as a primarily visceral-somatic region.(Uddin, Nomi et al. 2017) Studies have shown relation between functional connections of the basal ganglia and 
bioRxiv preprint doi: https://doi org/10.1101/2020.04.11.036954; this version posted April $13,2020$. The copyright holder for this preprint (which was not certified by peer review) is the author/funder, who has granted bioRxiv a license to display the preprint in perpetuity. It is made available under aCC-BY-NC-ND 4.0 International license.

insula and fatigue severity in case of MS patients.(Finke, Schlichting et al. 2014, Jaeger, Paul et al. 2018, Lin, Zivadinov et al. 2018)

ClusterZ revealed a cluster in the right caudate body with significant mean effect size of -0.57 . The mammalian basal ganglia structures, specifically the dorsal striatum, have been considered to have a role in memory and learning.(Packard and Knowlton 2002)

\section{Correlations of GM atrophy with clinical variables}

The occurrence of brain tissue loss is not quite uniform, being more evident in brain GM in case of progressive MS, affecting some cortical and DGM regions more than others (Bendfeldt, Hofstetter et al. 2012). In vivo MRI-clinical correlation studies have identified significant associations of GM atrophy with cognitive impairment, physical disability and progressive multiple sclerosis that are not dependent on other imaging abnormalities, such as white matter lesion load. All-in-all, there are compelling reasons to try to better understand the mechanisms of grey matter atrophy and the subsequent neurodegeneration that is reflected. (Chard and Miller 2016)

Thalamic volume is a candidate MRI-based marker associated with neurodegeneration that can be utilized to hasten development of neuroprotective treatments. According to the research

conducted by Azevedo and coworkers utilizing FreeSurfer longitudinal pipeline, decline in thalamic volume was observed to be significantly quicker in MS subjects compared to healthy controls $(\mathrm{HC})$ , with an estimated decline of $-0.71 \%$ per year $(95 \%$ confidence interval $[\mathrm{Cl}]=-0.77 \%$ to $-0.64 \%)$ in MS subjects and $-0.28 \%$ per year $(95 \% \mathrm{Cl}=-0.58 \%$ to $0.02 \%)$ in $\mathrm{HC}$ ( $\mathrm{p}$ for difference $=0.007$ ). The rate of decline was consistent throughout the MS disease duration and across MS clinical subtypes. Hence, thalamic atrophy was observed in early and consistently throughout the MS disease course, which is in agreement with the results of this study demonstrating correlation of disease duration with GM atrophy.(Azevedo, Cen et al. 2018) The authors pointed towards the deceleration of MS-specific brain volume change and the acceleration of age-related brain volume change during aging being more pronounced in the thalamus as compared to the whole brain, however it was not detectable in the putamen and caudate nuclei.

Datta and colleagues(Datta, Staewen et al. 2015) employed an automated pipeline based on tensor-based morphometry (TBM) to analyse GM atrophy in 1008 RRMS patients. Analysis of covariance was used to analyse atrophy differences between MS patients and $\mathrm{HC}$ on a voxel-byvoxel basis. Regional GM atrophy was observed in caudate, thalamus, putamen and cortical GM. Pearson's correlation coefficient was used to analyse correlations between regional GM volumes and EDSS scores, disease duration and other variables. Weak correlations between thalamic volume and EDSS $(r=-0.133 ; p<0.001)$ and DD $(r=-0.098 ; p=0.003)$ were observed.

Significantly lower cortical and subcortical volumes have been reported in the insula, caudate, thalamus, putamen, amygdala and hippocampus by a cross-sectional VBM analysis of 3T T1weighted MRI conducted by Palotai et al.(Palotai, Nazeri et al. 2019), adjusted for age, sex, disease duration and EDSS.

The present CBMA study results support these previous observations, taking into consideration the significant correlation between GM atrophy in the bilateral thalamus and MS disease duration.

\section{Previous meta-analyses conducted}

A similar coordinate based meta-analysis in MS was conducted at the same time as the present study (Chiang, Wang et al. 2019). That study used the popular activation likelihood estimate (ALE) (Turkeltaub, Eden et al. 2002, Laird, Fox et al. 2005, Eickhoff, Laird et al. 2009, Turkeltaub, Eickhoff et al. 2012) algorithm. There are some limitations to the ALE algorithm that warrants consideration of the presented analysis using ClusterZ. Firstly, the ALE algorithm cannot account for studies reporting no coordinates, while ClusterZ considers these through censoring; ignoring such studies biases the analysis to the most significant results. Furthermore, the ALE algorithm works voxel-wise rather than cluster-wise, making it difficult to assess significance in merged 
bioRxiv preprint doi: https://doi.org/10.1101/2020.04.11.036954 this version posted April 13, 2020. The copyright holder for this preprint (which was not certified by peer review) is the author/funder, who has granted bioRxiv a license to display the preprint in perpetuity. It is made available under aCC-BY-NC-ND 4.0 International license.

clusters such as the left and right thalamic cluster, which is separated by the ClusterZ algorithm. Finally, excluding the reported $Z$ scores puts meta-regression beyond the ALE algorithm. Nevertheless, the two analyses have produced remarkably similar results.

\section{Limitations}

Even a well-performed meta-analysis of badly designed studies is bound to yield results that may contain inaccuracies. Bias and methodological limitations in the primary studies might be reflected in the meta-analysis. In the case of imaging studies methodological problems such as the use of uncorrected $p$-values are common. Coordinate based meta-analysis selects those results from the primary studies that are most concordant across the studies, and therefore goes some way to mitigate these problems. Nevertheless, CBMA results should be considered hypothesis generating in general and used to inform design of robust prospective studies. To this end the presented ClusterZ results provide a-priori regions of interest for testing as well as statistical effect size estimation for sample size calculations.

\section{Summary}

GM atrophy regions involving the dorsal striatum, primary somatosensory cortex, insular cortex, auditory cortex and the relay station of the brain were identified cortically and subcortically in this meta-analysis of VBM studies of multiple sclerosis. The regions demonstrating significant effect sizes involved cortical and DGM regions, namely- bilateral Thalamus, bilateral BA3, Putamen, Caudate, BA13 and Superior temporal gyrus. Furthermore, disease duration was found to be a significant correlate of the standardized reported effect sizes in the thalamic clusters. These regions and the statistical effect size distributions can be used to design robust prospective studies of GM atrophy in MS. 
bioRxiv preprint doi: https://doi.org/10.1101/2020.04.11.036954; this version posted April 13, 2020. The copyright holder for this preprint (which was not certified by peer review) is the author/funder, who has granted bioRxiv a license to display the preprint in perpetuity. It is made available under aCC-BY-NC-ND 4.0 International license.

\section{References}

Abutalebi, J., P. A. Della Rosa, D. W. Green, M. Hernandez, P. Scifo, R. Keim, S. F. Cappa and A. Costa (2012). "Bilingualism tunes the anterior cingulate cortex for conflict monitoring." Cereb Cortex 22(9): 2076-2086. Achiron, A., J. Chapman, S. Tal, E. Bercovich, H. Gil and A. Achiron (2013). "Superior temporal gyrus thickness correlates with cognitive performance in multiple sclerosis." Brain Struct Funct 218(4): 943-950.

Anderson, V. M., K. T. Fernando, G. R. Davies, W. Rashid, C. Frost, N. C. Fox and D. H. Miller (2007). "Cerebral atrophy measurement in clinically isolated syndromes and relapsing remitting multiple sclerosis: a comparison of registration-based methods." J Neuroimaging 17(1): 61-68.

Angelini, D. F., B. Serafini, E. Piras, M. Severa, E. M. Coccia, B. Rosicarelli, S. Ruggieri, C. Gasperini, F. Buttari, D. Centonze, R. Mechelli, M. Salvetti, G. Borsellino, F. Aloisi and L. Battistini (2013). "Increased CD8+ T cell response to Epstein-Barr virus lytic antigens in the active phase of multiple sclerosis." PLoS Pathog 9(4): e1003220.

Audoin, B., G. R. Davies, L. Finisku, D. T. Chard, A. J. Thompson and D. H. Miller (2006). "Localization of grey matter atrophy in early RRMS : A longitudinal study." J Neurol 253(11): 1495-1501.

Audoin, B., W. Zaaraoui, F. Reuter, A. Rico, I. Malikova, S. Confort-Gouny, P. J. Cozzone, J. Pelletier and J.-P. Ranjeva (2010). "Atrophy mainly affects the limbic system and the deep grey matter at the first stage of multiple sclerosis." Journal of neurology, neurosurgery, and psychiatry 81(6): 690-695.

Azevedo, C. J., S. Y. Cen, S. Khadka, S. Liu, J. Kornak, Y. Shi, L. Zheng, S. L. Hauser and D. Pelletier (2018). "Thalamic atrophy in multiple sclerosis: A magnetic resonance imaging marker of neurodegeneration throughout disease." Ann Neurol 83(2): 223-234.

Azevedo, C. J., E. Overton, S. Khadka, J. Buckley, S. Liu, M. Sampat, O. Kantarci, C. Lebrun Frenay, A. Siva, D. T. Okuda and D. Pelletier (2015). "Early CNS neurodegeneration in radiologically isolated syndrome." Neurology(R) neuroimmunology \& neuroinflammation 2(3): e102-e102.

Baltruschat, S. A., N. Ventura-Campos, Á. J. Cruz-Gómez, A. Belenguer and C. Forn (2015). "Gray matter atrophy is associated with functional connectivity reorganization during the Paced Auditory Serial Addition Test (PASAT) execution in Multiple Sclerosis (MS)." Journal of Neuroradiology 42(3): 141-149.

Baranzini, S. E., R. Srinivasan, P. Khankhanian, D. T. Okuda, S. J. Nelson, P. M. Matthews, S. L. Hauser, J. R. Oksenberg and D. Pelletier (2010). "Genetic variation influences glutamate concentrations in brains of patients with multiple sclerosis." Brain 133(9): 2603-2611.

Batista, S., R. Zivadinov, M. Hoogs, N. Bergsland, M. Heininen-Brown, M. G. Dwyer, B. Weinstock-Guttman and R. H. Benedict (2012). "Basal ganglia, thalamus and neocortical atrophy predicting slowed cognitive processing in multiple sclerosis." J Neurol 259(1): 139-146.

Bendfeldt, K., L. Hofstetter, P. Kuster, S. Traud, N. Mueller-Lenke, Y. Naegelin, L. Kappos, A. Gass, T. E. Nichols, F. Barkhof, H. Vrenken, S. D. Roosendaal, J. J. G. Geurts, E.-W. Radue and S. J. Borgwardt (2012). "Longitudinal gray matter changes in multiple sclerosis--differential scanner and overall disease-related effects." Human brain mapping 33(5): 1225-1245.

Benjamini, Y. and Y. Hochberg (1995). "Controlling The False Discovery Rate - A Practical And Powerful Approach To Multiple Testing." J. Royal Statist. Soc., Series B 57: 289-300.

Bennett, C. M., G. L. Wolford and M. B. Miller (2009). "The principled control of false positives in neuroimaging." Soc Cogn Affect Neurosci 4(4): 417-422.

Bergsland, N., D. Horakova, M. G. Dwyer, O. Dolezal, Z. K. Seidl, M. Vaneckova, J. Krasensky, E. Havrdova and R. Zivadinov (2012). "Subcortical and cortical gray matter atrophy in a large sample of patients with clinically isolated syndrome and early relapsing-remitting multiple sclerosis." AJNR Am J Neuroradiol 33(8): 1573-1578.

Bigler, E. D., S. Mortensen, E. S. Neeley, S. Ozonoff, L. Krasny, M. Johnson, J. Lu, S. L. Provencal, W. McMahon and J. E. Lainhart (2007). "Superior temporal gyrus, language function, and autism." Dev Neuropsychol 31(2): 217-238. Bisecco, A., S. Stamenova, G. Caiazzo, A. d'Ambrosio, R. Sacco, R. Docimo, S. Esposito, M. Cirillo, F. Esposito, S. Bonavita, G. Tedeschi and A. Gallo (2018). "Attention and processing speed performance in multiple sclerosis is mostly related to thalamic volume." Brain imaging and behavior 12(1): 20-28.

Bodini, B., Z. Khaleeli, M. Cercignani, D. H. Miller, A. J. Thompson and O. Ciccarelli (2009). "Exploring the relationship between white matter and gray matter damage in early primary progressive multiple sclerosis: An in vivo study with TBSS and VBM." Human Brain Mapping 30(9): 2852-2861.

Bonavita, S., A. Gallo, R. Sacco, M. D. Corte, A. Bisecco, R. Docimo, L. Lavorgna, D. Corbo, A. D. Costanzo, F. Tortora, M. Cirillo, F. Esposito and G. Tedeschi (2011). "Distributed changes in default-mode resting-state connectivity in multiple sclerosis." Mult Scler 17(4): 411-422.

Borkosky, S. S., C. Whitley, A. Kopp-Schneider, H. zur Hausen and E. M. de Villiers (2012). "Epstein-Barr virus stimulates torque teno virus replication: a possible relationship to multiple sclerosis." PLoS One 7(2): e32160. 
bioRxiv preprint doi: https://doi.org/10.1101/2020.04.11.036954; this version posted April 13,2020 . The copyright holder for this preprint (which was not certified by peer review) is the author/funder, who has granted bioRxiv a license to display the preprint in perpetuity. It is made available under aCC-BY-NC-ND 4.0 International license.

Button, K. S., J. P. A. loannidis, C. Mokrysz, B. A. Nosek, J. Flint, E. S. J. Robinson and M. R. Munafò (2013). "Power failure: why small sample size undermines the reliability of neuroscience." Nature Reviews Neuroscience $14: 365$. Calabrese, M., M. Atzori, V. Bernardi, A. Morra, C. Romualdi, L. Rinaldi, M. J. M. McAuliffe, L. Barachino, P. Perini, B. Fischl, L. Battistin and P. Gallo (2007). "Cortical atrophy is relevant in multiple sclerosis at clinical onset." Journal of Neurology 254(9): 1212.

Ceccarelli, A., M. A. Rocca, E. Pagani, B. Colombo, V. Martinelli, G. Comi and M. Filippi (2008). "A voxel-based morphometry study of grey matter loss in MS patients with different clinical phenotypes." Neuroimage 42(1): 315322.

Ceccarelli, A., M. A. Rocca, E. Pagani, A. Ghezzi, R. Capra, A. Falini, G. Scotti, G. Comi and M. Filippi (2008). "The topographical distribution of tissue injury in benign MS: a 3T multiparametric MRI study." Neurolmage 39(4): 14991509.

Ceccarelli, A., M. A. Rocca, P. Valsasina, M. Rodegher, E. Pagani, A. Falini, G. Comi and M. Filippi (2009). "A multiparametric evaluation of regional brain damage in patients with primary progressive multiple sclerosis." $\underline{\text { Human }}$ Brain Mapping 30(9): 3009-3019.

Cerasa, A., P. Valentino, C. Chiriaco, D. Pirritano, R. Nisticò, C. M. Gioia, M. Trotta, F. Del Giudice, T. Tallarico, F. Rocca, A. Augimeri, G. Bilotti and A. Quattrone (2013). "MR imaging and cognitive correlates of relapsing-remitting multiple sclerosis patients with cerebellar symptoms." Journal of neurology 260(5): 1358-1366.

Chard, D. T. and D. H. Miller (2016). "What lies beneath grey matter atrophy in multiple sclerosis?" Brain 139(Pt 1): 710.

Chiang, F. L., Q. Wang, F. F. Yu, R. S. Romero, S. Y. Huang, P. M. Fox, B. Tantiwongkosi and P. T. Fox (2019). "Localised grey matter atrophy in multiple sclerosis is network-based: a coordinate-based meta-analysis." Clin Radiol 74(10): 816.e819-816.e828.

Cifelli, A., M. Arridge, P. Jezzard, M. M. Esiri, J. Palace and P. M. Matthews (2002). "Thalamic neurodegeneration in multiple sclerosis." Ann Neurol 52(5): 650-653.

Confavreux , C., S. Vukusic , T. Moreau and P. Adeleine (2000). "Relapses and Progression of Disability in Multiple Sclerosis." New England Journal of Medicine 343(20): 1430-1438.

Dale, A. M., B. Fischl and M. I. Sereno (1999). "Cortical surface-based analysis. I. Segmentation and surface reconstruction." Neuroimage 9(2): 179-194.

Dalton, C. M., D. T. Chard, G. R. Davies, K. A. Miszkiel, D. R. Altmann, K. Fernando, G. T. Plant, A. J. Thompson and D. H. Miller (2004). "Early development of multiple sclerosis is associated with progressive grey matter atrophy in patients presenting with clinically isolated syndromes." Brain 127(5): 1101-1107.

Datta, S., T. D. Staewen, S. S. Cofield, G. R. Cutter, F. D. Lublin, J. S. Wolinsky and P. A. Narayana (2015). "Regional gray matter atrophy in relapsing remitting multiple sclerosis: baseline analysis of multi-center data." Mult Scler Relat Disord 4(2): 124-136.

De Stefano, N., P. M. Matthews, M. Filippi, F. Agosta, M. De Luca, M. L. Bartolozzi, L. Guidi, A. Ghezzi, E. Montanari, A. Cifelli, A. Federico and S. M. Smith (2003). "Evidence of early cortical atrophy in MS: relevance to white matter changes and disability." Neurology 60(7): 1157-1162.

Debernard, L., T. R. Melzer, S. Van Stockum, C. Graham, C. A. Wheeler-Kingshott, J. C. Dalrymple-Alford, D. H. Miller and D. F. Mason (2014). "Reduced grey matter perfusion without volume loss in early relapsing-remitting multiple sclerosis." Journal of neurology, neurosurgery, and psychiatry 85(5): 544-551.

Doche, E., A. Lecocq, A. Maarouf, G. Duhamel, E. Soulier, S. Confort-Gouny, A. Rico, M. Guye, B. Audoin, J. Pelletier, J. P. Ranjeva and W. Zaaraoui (2017). "Hypoperfusion of the thalamus is associated with disability in relapsing remitting multiple sclerosis." J Neuroradiol 44(2): 158-164.

Eickhoff, S. B., A. R. Laird, C. Grefkes, L. E. Wang, K. Zilles and P. T. Fox (2009). "Coordinate-based activation likelihood estimation meta-analysis of neuroimaging data: a random-effects approach based on empirical estimates of spatial uncertainty." Hum Brain Mapp 30(9): 2907-2926.

Eshaghi, A., B. Bodini, G. R. Ridgway, D. García-Lorenzo, D. J. Tozer, M. A. Sahraian, A. J. Thompson and O. Ciccarelli (2014). "Temporal and spatial evolution of grey matter atrophy in primary progressive multiple sclerosis."

Neurolmage 86(100): 257-264.

Fama, R. and E. V. Sullivan (2015). "Thalamic structures and associated cognitive functions: Relations with age and aging." Neuroscience and biobehavioral reviews 54: 29-37.

Finke, C., J. Schlichting, S. Papazoglou, M. Scheel, A. Freing, C. Soemmer, L. Pech, A. Pajkert, C. Pfüller, J. Wuerfel, C. Ploner, F. Paul and A. Brandt (2014). Altered basal ganglia functional connectivity in multiple sclerosis patients with fatigue.

Fischl, B., M. I. Sereno and A. M. Dale (1999). "Cortical surface-based analysis. II: Inflation, flattening, and a surfacebased coordinate system." Neuroimage 9(2): 195-207. 
bioRxiv preprint doi: https://doi.org/10.1101/2020.04.11.036954; this version posted April 13,2020 . The copyright holder for this preprint (which was not certified by peer review) is the author/funder, who has granted bioRxiv a license to display the preprint in perpetuity. It is made available under aCC-BY-NC-ND 4.0 International license.

Fisher, E., J. C. Lee, K. Nakamura and R. A. Rudick (2008). "Gray matter atrophy in multiple sclerosis: a longitudinal study." Ann Neurol 64(3): 255-265.

Fisniku, L. K., D. T. Chard, J. S. Jackson, V. M. Anderson, D. R. Altmann, K. A. Miszkiel, A. J. Thompson and D. H. Miller (2008). "Gray matter atrophy is related to long-term disability in multiple sclerosis." Ann Neurol 64(3): 247-254. Friederici, A. D. (2012). "The cortical language circuit: from auditory perception to sentence comprehension." Trends Cogn Sci 16(5): 262-268.

Gallo, A., F. Esposito, R. Sacco, R. Docimo, A. Bisecco, M. Della Corte, A. D'Ambrosio, D. Corbo, N. Rosa, M. Lanza, S. Cirillo, S. Bonavita and G. Tedeschi (2012). "Visual resting-state network in relapsing-remitting MS with and without previous optic neuritis." Neurology 79(14): 1458-1465.

Geurts, J. J. G. and F. Barkhof (2008). "Grey matter pathology in multiple sclerosis." The Lancet Neurology 7(9): 841851.

Gilmore, C. P., I. Donaldson, L. Bö, T. Owens, J. Lowe and N. Evangelou (2009). "Regional variations in the extent and pattern of grey matter demyelination in multiple sclerosis: a comparison between the cerebral cortex, cerebellar cortex, deep grey matter nuclei and the spinal cord." J Neurol Neurosurg Psychiatry 80(2): 182-187.

Gobbi, C., M. A. Rocca, G. Riccitelli, E. Pagani, R. Messina, P. Preziosa, B. Colombo, M. Rodegher, A. Falini, G. Comi and M. Filippi (2014). "Influence of the topography of brain damage on depression and fatigue in patients with multiple sclerosis." Multiple Sclerosis Journal 20(2): 192-201.

Gomez, A. J. C., N. V. Campos, A. Belenguer, C. Avila and C. Forn (2013). "Regional Brain Atrophy and Functional Connectivity Changes Related to Fatigue in Multiple Sclerosis." Plos One 8(10).

Haider, L., C. Simeonidou, G. Steinberger, S. Hametner, N. Grigoriadis, G. Deretzi, G. G. Kovacs, A. Kutzelnigg, H. Lassmann and J. M. Frischer (2014). "Multiple sclerosis deep grey matter: the relation between demyelination, neurodegeneration, inflammation and iron." J Neurol Neurosurg Psychiatry 85(12): 1386-1395.

Han, X. M., H. J. Tian, Z. Han, C. Zhang, Y. Liu, J. B. Gu, R. Bakshi and X. Cao (2017). "Correlation between white matter damage and gray matter lesions in multiple sclerosis patients." Neural Regen Res 12(5): 787-794.

Henry, R. G., M. Shieh, D. T. Okuda, A. Evangelista, M. L. Gorno-Tempini and D. Pelletier (2008). "Regional grey matter atrophy in clinically isolated syndromes at presentation." J Neurol Neurosurg Psychiatry 79(11): 1236-1244. Houtchens, M. K., R. H. Benedict, R. Killiany, J. Sharma, Z. Jaisani, B. Singh, B. Weinstock-Guttman, C. R. Guttmann and R. Bakshi (2007). "Thalamic atrophy and cognition in multiple sclerosis." Neurology 69(12): 1213-1223. Jaeger, S., F. Paul, M. Scheel, A. Brandt, J. Heine, D. Pach, C. M. Witt, J. Bellmann-Strobl and C. Finke (2018). "Multiple sclerosis-related fatigue: Altered resting-state functional connectivity of the ventral striatum and dorsolateral prefrontal cortex." Mult Scler: 1352458518758911.

Khaleeli, Z., M. Cereignani, B. Audoin, O. Ciccarelli, D. H. Miller and A. J. Thompson (2007). "Localized grey matter damage in early primary progressive multiple sclerosis contributes to disability." Neuroimage 37(1): 253-261. Klaver, R., H. E. De Vries, G. J. Schenk and J. J. G. Geurts (2013). "Grey matter damage in multiple sclerosis: a pathology perspective." Prion 7(1): 66-75.

Koikkalainen, J., J. Hirvonen, M. Nyman, J. Lotjonen, J. Hietala and U. Ruotsalainen (2007). "Shape variability of the human striatum--Effects of age and gender." Neuroimage 34(1): 85-93.

Koskimäki, F., J. Bernard, J. Yong, N. Arndt, T. Carroll, S. K. Lee, A. T. Reder and A. Javed (2018). "Gray matter atrophy in multiple sclerosis despite clinical and lesion stability during natalizumab treatment." PLoS One 13(12): e0209326. Kramer, J., S. G. Meuth, J. G. Tenberge, P. Schiffler, H. Wiendl and M. Deppe (2015). "Early and Degressive Putamen Atrophy in Multiple Sclerosis." Int J Mol Sci 16(10): 23195-23209.

Laird, A. R., P. M. Fox, C. J. Price, D. C. Glahn, A. M. Uecker, J. L. Lancaster, P. E. Turkeltaub, P. Kochunov and P. T. Fox (2005). "ALE meta-analysis: controlling the false discovery rate and performing statistical contrasts." Hum Brain Mapp 25(1): 155-164.

Lassmann, H. (2014). "Multiple sclerosis: lessons from molecular neuropathology." Exp Neurol 262 Pt A: 2-7. Lassmann, H., G. Niedobitek, F. Aloisi and J. M. Middeldorp (2011). "Epstein-Barr virus in the multiple sclerosis brain: a controversial issue--report on a focused workshop held in the Centre for Brain Research of the Medical University of Vienna, Austria." Brain 134(Pt 9): 2772-2786.

Leff, A. P., T. M. Schofield, J. T. Crinion, M. L. Seghier, A. Grogan, D. W. Green and C. J. Price (2009). "The left superior temporal gyrus is a shared substrate for auditory short-term memory and speech comprehension: evidence from 210 patients with stroke." Brain : a journal of neurology 132(Pt 12): 3401-3410.

Li, Y., V. Jewells, M. Kim, Y. Chen, A. Moon, D. Armao, L. Troiani, S. Markovic-Plese, W. Lin and D. Shen (2013). "Diffusion tensor imaging based network analysis detects alterations of neuroconnectivity in patients with clinically early relapsing-remitting multiple sclerosis." Hum Brain Mapp 34(12): 3376-3391.

Liberati, A., D. G. Altman, J. Tetzlaff, C. Mulrow, P. C. Gøtzsche, J. P. A. Ioannidis, M. Clarke, P. J. Devereaux, J. Kleijnen and D. Moher (2009). "The PRISMA statement for reporting systematic reviews and meta-analyses of studies that evaluate healthcare interventions: explanation and elaboration." BMJ 339: b2700. 
bioRxiv preprint doi: https://doi.org/10.1101/2020.04.11.036954; this version posted April $13,2020$. The copyright holder for this preprint (which was not certified by peer review) is the author/funder, who has granted bioRxiv a license to display the preprint in perpetuity. It is made available under aCC-BY-NC-ND 4.0 International license.

Lin, A., F. Chen, F. Liu, Z. Li, Y. Liu, S. Lin, X. Wang and J. Zhu (2013). "Regional gray matter atrophy and neuropsychologcal problems in relapsing-remitting multiple sclerosis." Neural regeneration research 8(21): 19581965.

Lin, F., R. Zivadinov, J. Hagemeier, B. Weinstock-Guttman, C. Vaughn, S. Gandhi, D. Jakimovski, H. E. Hulst, R. H. Benedict, N. Bergsland, T. Fuchs and M. G. Dwyer (2018). "Altered nuclei-specific thalamic functional connectivity patterns in multiple sclerosis and their associations with fatigue and cognition." Mult Scler: 1352458518788218. Losseff, N. A., L. Wang, H. M. Lai, D. S. Yoo, M. L. Gawne-Cain, W. I. McDonald, D. H. Miller and A. J. Thompson (1996). "Progressive cerebral atrophy in multiple sclerosis. A serial MRI study." Brain 119 ( Pt 6): 2009-2019.

Lossius, A., J. N. Johansen, F. Vartdal, H. Robins, B. Jūratė Šaltytè, T. Holmøy and J. Olweus (2014). "High-throughput sequencing of TCR repertoires in multiple sclerosis reveals intrathecal enrichment of EBV-reactive CD8+ T cells." Eur J Immunol 44(11): 3439-3452.

Lublin, F. D. and S. C. Reingold (1996). "Defining the clinical course of multiple sclerosis: results of an international survey. National Multiple Sclerosis Society (USA) Advisory Committee on Clinical Trials of New Agents in Multiple Sclerosis." Neurology 46(4): 907-911.

Magliozzi, R., O. Howell, A. Vora, B. Serafini, R. Nicholas, M. Puopolo, R. Reynolds and F. Aloisi (2007). "Meningeal Bcell follicles in secondary progressive multiple sclerosis associate with early onset of disease and severe cortical pathology." Brain 130(Pt 4): 1089-1104.

Mastronardi, F. G. and M. A. Moscarello (2005). "Molecules affecting myelin stability: a novel hypothesis regarding the pathogenesis of multiple sclerosis." J Neurosci Res 80(3): 301-308.

McDonald, W. I., A. Compston, G. Edan, D. Goodkin, H.-P. Hartung, F. D. Lublin, H. F. McFarland, D. W. Paty, C. H. Polman, S. C. Reingold, M. Sandberg-Wollheim, W. Sibley, A. Thompson, S. Van Den Noort, B. Y. Weinshenker and J. S. Wolinsky (2001). "Recommended diagnostic criteria for multiple sclerosis: Guidelines from the international panel on the diagnosis of multiple sclerosis." Annals of Neurology 50(1): 121-127.

McDonald, W. I., A. Compston, G. Edan, D. Goodkin, H. P. Hartung, F. D. Lublin, H. F. McFarland, D. W. Paty, C. H. Polman, S. C. Reingold, M. Sandberg-Wollheim, W. Sibley, A. Thompson, S. van den Noort, B. Y. Weinshenker and J. S. Wolinsky (2001). "Recommended diagnostic criteria for multiple sclerosis: guidelines from the International Panel on the diagnosis of multiple sclerosis." Ann Neurol 50(1): 121-127.

Mesaros, S., M. Rovaris, E. Pagani, A. Pulizzi, D. Caputo, A. Ghezzi, A. Bertolotto, R. Capra, M. Falautano, V. Martinelli, G. Comi and M. Filippi (2008). "A magnetic resonance imaging voxel-based morphometry study of regional gray matter atrophy in patients with benign multiple sclerosis." Archives of Neurology 65(9): 1223-1230.

Messina, S. and F. Patti (2014). "Gray matters in multiple sclerosis: cognitive impairment and structural MRI." Mult Scler Int 2014: 609694.

Michl, P., T. Meindl, F. Meister, C. Born, R. R. Engel, M. Reiser and K. Hennig-Fast (2014). "Neurobiological underpinnings of shame and guilt: a pilot fMRI study." Social cognitive and affective neuroscience 9(2): 150-157. Miller, D. H., F. Barkhof, J. A. Frank, G. J. Parker and A. J. Thompson (2002). "Measurement of atrophy in multiple sclerosis: pathological basis, methodological aspects and clinical relevance." Brain 125(Pt 8): 1676-1695.

Modica, C. M., R. Zivadinov, M. G. Dwyer, N. Bergsland, A. R. Weeks and R. H. B. Benedict (2015). "Iron and Volume in the Deep Gray Matter: Association with Cognitive Impairment in Multiple Sclerosis." American Journal of Neuroradiology 36(1): 57.

Morgen, K., G. Sammer, S. M. Courtney, T. Wolters, H. Melchior, C. R. Blecker, P. Oschmann, M. Kaps and D. Vaitl (2006). "Evidence for a direct association between cortical atrophy and cognitive impairment in relapsing-remitting MS." Neuroimage 30(3): 891-898.

Muhlau, M., D. Buck, A. Forschler, C. C. Boucard, M. Arsic, P. Schmidt, C. Gaser, A. Berthele, M. Hoshi, A. Jochim, H. Kronsbein, C. Zimmer, B. Hemmer and R. Ilg (2013). "White-matter lesions drive deep gray-matter atrophy in early multiple sclerosis: support from structural MRI." Mult Scler 19(11): 1485-1492.

Munakomi., M. G. S. Neuroanatomy, Putamen, StatPearls.

Neumann, H., A. Cavalié, D. E. Jenne and H. Wekerle (1995). "Induction of MHC class I genes in neurons." Science 269(5223): 549-552.

Oberhuber, M., Ō. Parker Jones, T. M. H. Hope, S. Prejawa, M. Seghier, D. Green and C. Price (2013). "Functionally distinct contributions of the anterior and posterior putamen during sublexical and lexical reading." Frontiers in Human Neuroscience 7 (787).

Packard, M. G. and B. J. Knowlton (2002). "Learning and memory functions of the Basal Ganglia." Annu Rev Neurosci 25: 563-593.

Palotai, M., A. Nazeri, M. Cavallari, B. C. Healy, B. Glanz, S. M. Gold, H. L. Weiner, T. Chitnis and C. R. G. Guttmann (2019). "History of fatigue in multiple sclerosis is associated with grey matter atrophy." Scientific Reports 9(1): 14781. 
bioRxiv preprint doi: https://doi.org/10.1101/2020.04.11.036954; this version posted April 13,2020 . The copyright holder for this preprint (which was not certified by peer review) is the author/funder, who has granted bioRxiv a license to display the preprint in perpetuity. It is made available under aCC-BY-NC-ND 4.0 International license.

Parisi, L., M. A. Rocca, F. Mattioli, G. C. Riccitelli, R. Capra, C. Stampatori, F. Bellomi and M. Filippi (2014). "Patterns of regional gray matter and white matter atrophy in cortical multiple sclerosis." Journal of Neurology 261(9): 17151725.

Patenaude, B., S. M. Smith, D. N. Kennedy and M. Jenkinson (2011). "A Bayesian model of shape and appearance for subcortical brain segmentation." Neuroimage 56(3): 907-922.

Polman, C. H., S. C. Reingold, B. Banwell, M. Clanet, J. A. Cohen, M. Filippi, K. Fujihara, E. Havrdova, M. Hutchinson, L. Kappos, F. D. Lublin, X. Montalban, P. O'Connor, M. Sandberg-Wollheim, A. J. Thompson, E. Waubant, B.

Weinshenker and J. S. Wolinsky (2011). "Diagnostic criteria for multiple sclerosis: 2010 Revisions to the McDonald criteria." Annals of Neurology 69(2): 292-302.

Polman, C. H., S. C. Reingold, G. Edan, M. Filippi, H. P. Hartung, L. Kappos, F. D. Lublin, L. M. Metz, H. F. McFarland, P. W. O'Connor, M. Sandberg-Wollheim, A. J. Thompson, B. G. Weinshenker and J. S. Wolinsky (2005). "Diagnostic criteria for multiple sclerosis: 2005 revisions to the "McDonald Criteria"." Ann Neurol 58(6): 840-846.

Popescu, V., M. M. Schoonheim, A. Versteeg, N. Chaturvedi, M. Jonker, R. Xavier de Menezes, F. Gallindo Garre, B. M. Uitdehaag, F. Barkhof and H. Vrenken (2016). "Grey Matter Atrophy in Multiple Sclerosis: Clinical Interpretation Depends on Choice of Analysis Method." PLoS One 11(1): e0143942.

Poser, C. M., D. W. Paty, L. Scheinberg, W. I. McDonald, F. A. Davis, G. C. Ebers, K. P. Johnson, W. A. Sibley, D. H. Silberberg and W. W. Tourtellotte (1983). "New diagnostic criteria for multiple sclerosis: Guidelines for research protocols." Annals of Neurology 13(3): 227-231.

Prakash, R. S., E. M. Snook, R. W. Motl and A. F. Kramer (2010). "Aerobic fitness is associated with gray matter volume and white matter integrity in multiple sclerosis." Brain Research 1341: 41-51.

Prinster, A., M. Quarantelli, G. Orefice, R. Lanzillo, A. Brunetti, C. Mollica, E. Salvatore, V. B. Morra, G. Coppola, G. Vacca, B. Alfano and M. Salvatore (2006). "Grey matter loss in relapsing-remitting multiple sclerosis: A voxel-based morphometry study." Neuroimage 29(3): 859-867.

Radua, J., M. L. Phillips, T. Russell, N. Lawrence, N. Marshall, S. Kalidindi, W. El-Hage, C. McDonald, V. Giampietro, M. J. Brammer, A. S. David and S. A. Surguladze (2010). "Neural response to specific components of fearful faces in healthy and schizophrenic adults." Neuroimage 49(1): 939-946.

Riccitelli, G., M. A. Rocca, C. Forn, B. Colombo, G. Comi and M. Filippi (2011). "Voxelwise assessment of the regional distribution of damage in the brains of patients with multiple sclerosis and fatigue." AJNR. American journal of neuroradiology 32(5): 874-879.

Riccitelli, G., M. A. Rocca, E. Pagani, V. Martinelli, M. Radaelli, A. Falini, G. Comi and M. Filippi (2012). "Mapping regional grey and white matter atrophy in relapsing-remitting multiple sclerosis." Multiple sclerosis (Houndmills, Basingstoke, England) 18(7): 1027-1037.

Sailer, M., B. Fischl, D. Salat, C. Tempelmann, M. A. Schonfeld, E. Busa, N. Bodammer, H. J. Heinze and A. Dale (2003). "Focal thinning of the cerebral cortex in multiple sclerosis." Brain 126(Pt 8): 1734-1744.

Sanchis-Segura, C., A. J. Cruz-Gomez, A. Belenguer, M. S. Fittipaldi Marquez, C. Avila and C. Forn (2016). "Increased regional gray matter atrophy and enhanced functional connectivity in male multiple sclerosis patients." Neurosci Lett 630: 154-157.

Sander, J., M. Ester, H.-P. Kriegel and X. Xu (1998). "Density-Based Clustering in Spatial Databases: The Algorithm GDBSCAN and Its Applications." Data Mining and Knowledge Discovery 2(2): 169-194.

Sargsyan, S. A., A. J. Shearer, A. M. Ritchie, M. P. Burgoon, S. Anderson, B. Hemmer, C. Stadelmann, S. Gattenlöhner, G. P. Owens, D. Gilden and J. L. Bennett (2010). "Absence of Epstein-Barr virus in the brain and CSF of patients with multiple sclerosis." Neurology 74(14): 1127-1135.

Scarpazza, C., S. Tognin, S. Frisciata, G. Sartori and A. Mechelli (2015). "False positive rates in Voxel-based Morphometry studies of the human brain: should we be worried?" Neurosci Biobehav Rev 52: 49-55.

Sepulcre, J., J. Sastre-Garriga, M. Cercignani, G. T. Ingle, D. H. Miller and A. J. Thompson (2006). "Regional gray matter atrophy in early primary progressive multiple sclerosis: a voxel-based morphometry study." Arch Neurol 63(8): 1175-1180.

Smith, S. M., Y. Zhang, M. Jenkinson, J. Chen, P. M. Matthews, A. Federico and N. De Stefano (2002). "Accurate, robust, and automated longitudinal and cross-sectional brain change analysis." Neuroimage 17(1): 479-489.

Spano, B., M. Cercignani, B. Basile, S. Romano, R. Mannu, D. Centonze, C. Caltagirone, P. Bramanti, U. Nocentini and M. Bozzali (2010). "Multiparametric MR investigation of the motor pyramidal system in patients with 'truly benign' multiple sclerosis." Multiple Sclerosis 16(2): 178-188.

Stassart, R. M., W. Möbius, K. A. Nave and J. M. Edgar (2018). "The Axon-Myelin Unit in Development and Degenerative Disease." Front Neurosci 12: 467.

Štecková, T., P. Hluštík, V. Sládková, F. Odstrčil, J. Mareš and P. Kaňovský (2014). "Thalamic atrophy and cognitive impairment in clinically isolated syndrome and multiple sclerosis." Journal of the neurological sciences 342(1-2): 62 68. 
bioRxiv preprint doi: https://doi.org/10.1101/2020.04.11.036954; this version posted April $13,2020$. The copyright holder for this preprint (which was not certified by peer review) is the author/funder, who has granted bioRxiv a license to display the preprint in perpetuity. It is made available under aCC-BY-NC-ND 4.0 International license.

Talairach, J. a. P. T. (1988). Co-planar stereotaxic atlas of the human brain. New York, Thieme.

Tavazzi, E., M. M. Laganà, N. Bergsland, P. Tortorella, G. Pinardi, C. Lunetta, M. Corbo and M. Rovaris (2015). "Grey matter damage in progressive multiple sclerosis versus amyotrophic lateral sclerosis: a voxel-based morphometry MRI study." Neurological sciences : official journal of the Italian Neurological Society and of the Italian Society of Clinical Neurophysiology 36(3): 371-377.

Tedeschi, G., L. Lavorgna, P. Russo, A. Prinster, D. Dinacci, G. Savettieri, A. Quattrone, P. Livrea, C. Messina, A. Reggio, V. Bresciamorra, G. Orefice, M. Paciello, A. Brunetti, G. Coniglio, S. Bonavita, A. Di Costanzo, A. Bellacosa, P. Valentino, M. Quarantelli, F. Patti, G. Salemi, E. Cammarata, I. L. Simone, M. Salvatore, V. Bonavita and B. Alfano (2005). "Brain atrophy and lesion load in a large population of patients with multiple sclerosis." Neurology 65(2): 280-285.

Tench, C. R., R. Tanasescu, D. P. Auer, W. J. Cottam and C. S. Constantinescu (2014). "Coordinate Based MetaAnalysis of Functional Neuroimaging Data Using Activation Likelihood Estimation; Full Width Half Max and Group Comparisons." PLOS ONE 9(9): e106735.

Tench, C. R., R. Tanasescu, C. S. Constantinescu, D. P. Auer and W. J. Cottam (2017). "Coordinate based random effect size meta-analysis of neuroimaging studies." Neurolmage 153(Supplement C): 293-306.

Tench, C. R., R. Tanasescu, C. S. Constantinescu, D. P. Auer and W. J. Cottam (2017). "Coordinate based random effect size meta-analysis of neuroimaging studies." Neuroimage 153: 293-306.

Thompson, A. (2004). "Overview of primary progressive multiple sclerosis (PPMS): similarities and differences from other forms of MS, diagnostic criteria, pros and cons of progressive diagnosis." Mult Scler 10 Suppl 1: S2-7.

Thompson, A. J., X. Montalban, F. Barkhof, B. Brochet, M. Filippi, D. H. Miller, C. H. Polman, V. L. Stevenson and W. I. McDonald (2000). "Diagnostic criteria for primary progressive multiple sclerosis: a position paper." Ann Neurol 47(6): 831-835.

Trapp, B. D., J. Peterson, R. M. Ransohoff, R. Rudick, S. Mork and L. Bo (1998). "Axonal transection in the lesions of multiple sclerosis." N Engl J Med 338(5): 278-285.

Trapp, B. D. and P. K. Stys (2009). "Virtual hypoxia and chronic necrosis of demyelinated axons in multiple sclerosis." Lancet Neurol 8(3): 280-291.

Turkeltaub, P. E., G. F. Eden, K. M. Jones and T. A. Zeffiro (2002). "Meta-analysis of the functional neuroanatomy of single-word reading: method and validation." Neuroimage 16(3 Pt 1): 765-780.

Turkeltaub, P. E., S. B. Eickhoff, A. R. Laird, M. Fox, M. Wiener and P. Fox (2012). "Minimizing within-experiment and within-group effects in Activation Likelihood Estimation meta-analyses." Hum Brain Mapp 33(1): 1-13.

Uddin, L. Q., J. S. Nomi, B. Hébert-Seropian, J. Ghaziri and O. Boucher (2017). "Structure and Function of the Human Insula." Journal of clinical neurophysiology : official publication of the American Electroencephalographic Society 34(4): 300-306.

Uono, S., W. Sato, T. Kochiyama, Y. Kubota, R. Sawada, S. Yoshimura and M. Toichi (2017). "Putamen Volume is Negatively Correlated with the Ability to Recognize Fearful Facial Expressions." Brain Topogr 30(6): 774-784.

van de Pavert, S. H. P., N. Muhlert, V. Sethi, C. A. M. Wheeler-Kingshott, G. R. Ridgway, J. J. G. Geurts, M. Ron, T. A. Yousry, A. J. Thompson, D. H. Miller, D. T. Chard and O. Ciccarelli (2016). "DIR-visible grey matter lesions and atrophy in multiple sclerosis: partners in crime?" Journal of neurology, neurosurgery, and psychiatry 87(5): 461-467.

Wager, T. D., M. A. Lindquist, T. E. Nichols, H. Kober and J. X. Van Snellenberg (2009). "Evaluating the consistency and specificity of neuroimaging data using meta-analysis." Neurolmage 45(1 Suppl): S210-S221.

Weygandt, M., K. Wakonig, J. Behrens, L. Meyer-Arndt, E. Söder, A. U. Brandt, J. Bellmann-Strobl, K. Ruprecht, S. M. Gold, J.-D. Haynes and F. Paul (2018). "Brain activity, regional gray matter loss, and decision-making in multiple sclerosis." Multiple sclerosis (Houndmills, Basingstoke, England) 24(9): 1163-1173.

Willis, S. N., C. Stadelmann, S. J. Rodig, T. Caron, S. Gattenloehner, S. S. Mallozzi, J. E. Roughan, S. E. Almendinger, M. M. Blewett, W. Brück, D. A. Hafler and K. C. O'Connor (2009). "Epstein-Barr virus infection is not a characteristic feature of multiple sclerosis brain." Brain 132(Pt 12): 3318-3328.

Zarei, M. (2006). "Clinical characteristics of cortical multiple sclerosis." Journal of the Neurological Sciences 245(1): 53-58.

Zeis, T., U. Graumann, R. Reynolds and N. Schaeren-Wiemers (2008). "Normal-appearing white matter in multiple sclerosis is in a subtle balance between inflammation and neuroprotection." Brain 131(Pt 1): $288-303$.

Zhang, X., F. Zhang, D. Huang, L. Wu, L. Ma, H. Liu, Y. Zhao, S. Yu and J. Shi (2016). "Contribution of Gray and White Matter Abnormalities to Cognitive Impairment in Multiple Sclerosis." International journal of molecular sciences 18(1): 46. 